Prepared in cooperation with the

Massachusetts Department of Environmental Protection, Division of Watershed Management

\title{
Assessment of Data for Use in the Development of Nutrient Criteria for Massachusetts Rivers and Streams
}

Scientific Investigations Report 2007-5022 


\section{Assessment of Data for Use in the Development of Nutrient Criteria for Massachusetts Rivers and Streams}

By Marc J. Zimmerman and Kimberly W. Campo

Prepared in cooperation with the

Massachusetts Department of Environmental Protection,

Division of Watershed Management

Scientific Investigations Report 2007-5022 


\section{U.S. Department of the Interior DIRK KEMPTHORNE, Secretary}

\section{U.S. Geological Survey \\ Mark D. Myers, Director}

\section{U.S. Geological Survey, Reston, Virginia: 2007}

For product and ordering information:

World Wide Web: http://www.usgs.gov/pubprod

Telephone: 1-888-ASK-USGS

For more information on the USGS--the Federal source for science about the Earth, its natural and living resources, natural hazards, and the environment:

World Wide Web: http://www.usgs.gov

Telephone: 1-888-ASK-USGS

Any use of trade, product, or firm names is for descriptive purposes only and does not imply endorsement by the U.S. Government.

Although this report is in the public domain, permission must be secured from the individual copyright owners to reproduce any copyrighted materials contained within this report.

Suggested citation:

Zimmerman, M.J., and Campo, K.W., 2007, Assessment of data for use in the development of nutrient criteria for Massachusetts rivers and streams: U.S. Geological Survey Scientific Investigations Report 2007-5022, 44 p. 


\section{Contents}

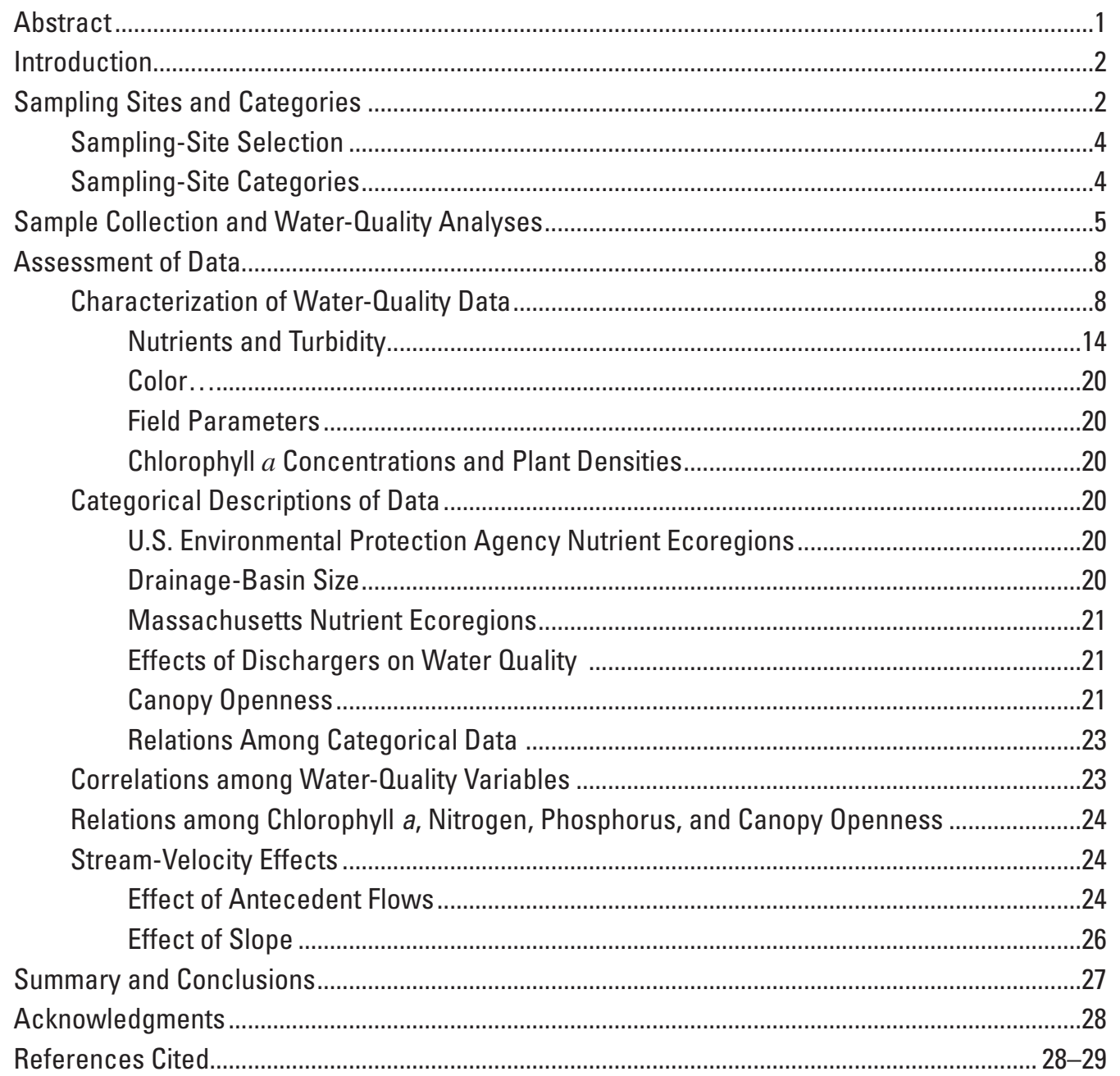

\section{Figures}

1. Map of Massachusetts showing sampling sites, presence of upstream National Pollutant Discharge Elimination System permitted dischargers, U.S. Environmental Protection Agency ecoregions, and Massachusetts nutrient ecoregions........................3

2-17. Graphs showing-

2. Distribution of median $(A)$ total phosphorus, $(B)$ total nitrogen, $(C)$ total dissolved nitrogen, and $(D)$ chlorophyll a concentrations at all sampling sites by year in Massachusetts.

3. Distribution of median $(A)$ total phosphorus, $(B)$ total nitrogen, $(C)$ total dissolved nitrogen, and $(D)$ chlorophyll a concentrations at 12 sampling sites by year in Massachusetts.

4. Distribution of median $(A)$ total phosphorus, $(B)$ total nitrogen, $(C)$ total dissolved nitrogen, and $(D)$ chlorophyll a concentrations at all sampling sites by ecoregion in Massachusetts. 
5. Distribution of median $(A)$ total phosphorus, $(B)$ total nitrogen, $(C)$ total dissolved nitrogen, and $(D)$ chlorophyll a concentrations at all sampling sites by Massachusetts nutrient ecoregion .16

6. Distribution of median $(A)$ total phosphorus, $(B)$ total nitrogen, $(C)$ total dissolved nitrogen, and $(D)$ chlorophyll a concentrations at all sampling sites by drainage-basin-size class in Massachusetts

7. Distribution of median $(A)$ total phosphorus, $(B)$ total nitrogen, $(C)$ total dissolved nitrogen, and $(D)$ chlorophyll a concentrations at all sampling sites by National Pollutant Discharge Elimination System discharger category in Massachusetts

8. Distribution of median periphyton chlorophyll a concentrations at $(A)$ closedand $(B)$ open-canopy sampling sites by Massachusetts nutrient ecoregion.

9. Distribution of median periphyton chlorophyll a concentrations at $(A)$ closedand $(B)$ open-canopy sampling sites for U.S. Environmental Protection Agency ecoregions VIII and XIV in Massachusetts.

10. Distribution of median periphyton chlorophyll a concentrations at $(A)$ closed- and

$(B)$ open-canopy sampling sites by drainage-basin-size class in Massachusetts

11. Distribution of median periphyton chlorophyll a concentrations at $(A)$ closedand $(B)$ open-canopy sampling sites by National Pollutant Discharge Elimination System discharger category in Massachusetts.

12. Density of $(A)$ filamentous periphyton, $(B)$ periphyton film, $(C)$ aquatic plants, $(D)$ aquatic moss, and $(E)$ periphyton floc as a function of median total phosphorus concentrations and the percentage of canopy openness at all sampling sites.....

13. Density of $(A)$ filamentous periphyton, $(B)$ periphyton film, $(C)$ aquatic plants, $(D)$ aquatic moss, and $(E)$ periphyton floc as a function of median total nitrogen concentrations and the percentage of canopy openness at all sampling sites.

14. Median $(A)$ total phosphorus and $(B)$ total nitrogen concentrations as a function of median chlorophyll a concentrations by Massachusetts nutrient ecoregion and National Pollutant Discharge Elimination System discharger category....

15. Median $(A, B)$ total phosphorus and $(C, D)$ total nitrogen concentrations as a function of median chlorophyll a concentrations at $(A, C)$ closed- and $(B, D)$ open-canopy sites by Massachusetts nutrient ecoregion and National Pollutant Discharge Elimination System discharger category

16. Median $(A)$ total phosphorus concentrations, $(B)$ total nitrogen concentrations, and $(C)$ ratio of total nitrogen to total phosphorus as a function of median chlorophyll a concentrations and percentage of canopy openness in Massachusetts.

17. Median $(A)$ total phosphorus, $(B)$ total nitrogen, $(C)$ total dissolved nitrogen, and $(D)$ chlorophyll a concentrations at all sampling sites as a function of slope in Massachusetts. 


\section{Tables}

1. U.S. Geological Survey water-quality stations, station identifiers, and ancillary information....

2. Summary statistics for median values of all water-quality parameters measured at sampling stations

3. Annual median water-quality data at sites that were sampled in 2001,2003 , and $2004 \ldots 12-13$

4. Twenty-fifth-percentile values for total phosphorus and total nitrogen concentrations and turbidity measured in U.S. Environmental Protection Agency ecoregions compared to values measured in this study and in Massachusetts low-, intermediate-, and high-nutrient ecoregions

5. Median values of representative data for stations in this report $17-19$

6. Correlation coefficients among major water-quality parameters and percentage of open canopy and drainage area.

7. Correlation coefficients among water-quality parameters, percentage of open canopy, and drainage area based on Massachusetts nutrient ecoregions

8. Regression coefficients for chlorophyll a versus total phosphorus, total nitrogen, the ratio of total nitrogen to total phosphorus, and percentage of open canopy for all sites, closed-canopy sites, and open-canopy sites 


\section{Conversion Factors, Horizontal Datum, and Abbreviations}

\begin{tabular}{|c|c|c|}
\hline \multicolumn{3}{|c|}{ SI to Inch/Pound } \\
\hline Multiply & By & To obtain \\
\hline centimeter $(\mathrm{cm})$ & 0.3937 & inch (in.) \\
\hline cubic meter per second $\left(\mathrm{m}^{3} / \mathrm{s}\right)$ & 70.07 & acre-foot per day (acre-ft/d) \\
\hline gram (g) & 0.03527 & ounce, avoirdupois (oz) \\
\hline kilometer $(\mathrm{km})$ & 0.6214 & mile (mi) \\
\hline liter (L) & 0.2642 & gallon (gal) \\
\hline meter per second $(\mathrm{m} / \mathrm{s})$ & 3.281 & foot per second (ft/s) \\
\hline square centimeter $\left(\mathrm{cm}^{2}\right)$ & 0.1550 & square inch $\left(\right.$ in $\left.^{2}\right)$ \\
\hline square meter $\left(\mathrm{m}^{2}\right)$ & 10.76 & square foot $\left(\mathrm{ft}^{2}\right)$ \\
\hline square kilometer $\left(\mathrm{km}^{2}\right)$ & 0.3861 & square mile $\left(\mathrm{mi}^{2}\right)$ \\
\hline \multicolumn{3}{|c|}{ Inch/Pound to SI } \\
\hline Multiply & By & To obtain \\
\hline acre-foot per day (acre-ft/d) & 0.01427 & cubic meter per second $\left(\mathrm{m}^{3} / \mathrm{s}\right)$ \\
\hline cubic foot per second $\left(\mathrm{ft}^{3} / \mathrm{s}\right)$ & 0.02832 & cubic meter per second $\left(\mathrm{m}^{3} / \mathrm{s}\right)$ \\
\hline foot per second (ft/s) & 0.3048 & meter per second $(\mathrm{m} / \mathrm{s})$ \\
\hline gallon (gal) & 0.003785 & cubic meter $\left(\mathrm{m}^{3}\right)$ \\
\hline gallon (gal) & 3.785 & liter (L) \\
\hline million gallons per day (Mgal/d) & 0.04381 & cubic meters per second $\left(\mathrm{m}^{3} / \mathrm{s}\right)$ \\
\hline inch (in.) & 2.54 & centimeter $(\mathrm{cm})$ \\
\hline mile (mi) & 1.609 & kilometer (km) \\
\hline ounce, avoirdupois (oz) & 28.35 & gram (g) \\
\hline square foot $\left(\mathrm{ft}^{2}\right)$ & 0.09290 & square meter $\left(\mathrm{m}^{2}\right)$ \\
\hline square inch $\left(\right.$ in $\left.^{2}\right)$ & 6.452 & square centimeter $\left(\mathrm{cm}^{2}\right)$ \\
\hline square mile $\left(\mathrm{mi}^{2}\right)$ & 2.590 & square kilometer $\left(\mathrm{km}^{2}\right)$ \\
\hline
\end{tabular}

Horizontal coordinate information is referenced to the North American Datum of 1983 (NAD 83).

Specific conductance is given in microsiemens per centimeter at 25 degrees Celsius $\left(\mu \mathrm{S} / \mathrm{cm}\right.$ at $\left.25^{\circ} \mathrm{C}\right)$.

Concentrations of chemical constituents in water are given in milligrams per liter (mg/L).

\section{Abbreviations}

DO
DWM
MassDEP
NPDES
NTU
NWOL
PCU
RPD
USEPA
USGS

Dissolved oxygen

Division of Watershed Management

Massachusetts Department of Environmental Protection

National Pollutant Discharge Elimination System

Nephelometric turbidity units

National Water Quality Laboratory

Platinum-cobalt units

Relative percent difference

U.S. Environmental Protection Agency

U.S. Geological Survey 


\title{
Assessment of Data for Use in the Development of Nutrient Criteria for Massachusetts Rivers and Streams
}

\author{
By Marc J. Zimmerman and Kimberly W. Campo
}

\section{Abstract}

The U.S. Geological Survey synthesized, reviewed, and assessed Massachusetts water-quality data for use in the development of either numerical nutrient criteria for rivers and streams or a science-based framework for interpreting narrative criterial for nutrients. Water-quality data collected from 65 Massachusetts locations were selected to represent a wide range, but not a statistical selection, of drainage basins and high-, intermediate-, and low-nutrient ecoregions. Additional sites were selected at some locations to provide data to compare open- and closed-canopy effects on periphyton chlorophyll $a$ concentrations. Nutrient and chlorophyll $a$ concentrations are the primary focus of this study. Data for turbidity, color, dissolved oxygen, specific conductance, $\mathrm{pH}$, and measures of aquatic-plant density also were examined. Water-quality data were analyzed by categories of year, ecoregion, drainage-basin size, Massachusetts nutrient ecoregion, presence of upstream wastewater dischargers, and canopy openness. Graphs and statistical analyses were used to evaluate data.

The U.S. Environmental Protection Agency (USEPA) recommends the 25th-percentile value of a waterquality constituent as the numerical nutrient criterion when using all available data for the constituent. In this study of Massachusetts waters, the 25th percentiles of median values at all sampling stations were: total phosphorus, 0.019 milligram per liter (mg/L); total nitrogen, $0.44 \mathrm{mg} / \mathrm{L}$; and turbidity, 1.2 nephelometric turbidity units (NTU). When the data are sorted by the two USEPA nutrient ecoregions in Massachusetts (VIII and XIV), the new values are: for Ecoregion VIII, total phosphorus, $0.009 \mathrm{mg} / \mathrm{L}$; total nitrogen, $0.289 \mathrm{mg} / \mathrm{L}$; and turbidity, 1.7 NTU; for Ecoregion XIV, total phosphorus, $0.028 \mathrm{mg} / \mathrm{L}$; total nitrogen, $0.583 \mathrm{mg} / \mathrm{L}$; and turbidity, 3.1 NTU. For the three Massachusetts lake-based nutrient ecoregions, the values are: high-nutrient ecoregion, total phosphorus, $0.030 \mathrm{mg} / \mathrm{L}$; total nitrogen, $0.642 \mathrm{mg} / \mathrm{L}$; and turbidity, $1.5 \mathrm{NTU}$; intermediate-nutrient ecoregion, total phosphorus, $0.016 \mathrm{mg} / \mathrm{L}$; total nitrogen, $0.419 \mathrm{mg} / \mathrm{L}$; and turbidity, 1.1 NTU; and low-nutrient ecoregion, total phosphorus, 0.011 $\mathrm{mg} / \mathrm{L}$; total nitrogen, $0.289 \mathrm{mg} / \mathrm{L}$; and turbidity, 0.7 NTU.
In general, median nutrient concentrations were found to be higher in the three following categories of analysis than in their complementary groups: sites in USEPA nutrient Ecoregion XIV, sites downstream from major National Pollutant Discharge Elimination System-permitted wastewater dischargers, and sites in the Massachusetts high-nutrient ecoregion. The largest drainage-basin size class had higher median nitrogen (total and dissolved) concentrations than the smallest, but total median phosphorus concentrations were not significantly different. Median chlorophyll $a$ concentrations did not vary significantly among the categories analyzed. The effects of open and closed canopies on median chlorophyll $a$ concentrations were greater within groups defined by the categories used in this study than between the groups; open-canopy sites generally had higher median chlorophyll $a$ concentrations than closed-canopy sites. More than 40 percent of the sampling stations were located downstream from major wastewater dischargers, and these dischargers were disproportionately located in USEPA Ecoregion XIV and the Massachusetts high-nutrient ecoregion and thus may constitute the same effect on water quality.

A number of expected relations among parameters analyzed did not materialize. Chlorophyll $a$ did not correlate well with any other parameters. No strong relations among the categories and nutrient concentrations or canopy openness were apparent. The occurrence of antecedent flows exceeding mean annual discharges by 300 percent within 28 days of sample collection did not correlate with decreases in chlorophyll $a$ concentrations that might have resulted from scouring associated with increasing velocities. No relation was apparent between a measure of stream slope (another surrogate for velocity) and nutrient or chlorophyll $a$ concentrations.

The relatively small number of sites in some of the categories analyzed and the presence of wastewater-treatment facilities on many of the streams made it difficult to definitively interpret the effects of the different groups within descriptive categories. A long-term sampling program providing representative data from a wider variety of streams than were sampled for this study, could yield a more robust dataset for analysis. 


\section{Introduction}

The U.S. Environmental Protection Agency (USEPA) has the responsibility for ensuring that water-quality standards are met in the Nation's waterways and other bodies of water. The USEPA may also be responsible for enforcement actions when these standards are not met. Individual States are responsible for establishing water-quality standards, evaluating water quality, and reporting violations of particular standards to the USEPA. The USEPA has promulgated guidance water-quality criteria for States to use as starting points in the establishment of their own criteria that protect designated uses of rivers and streams and that reflect local conditions (U.S. Environmental Protection Agency, 2000, 2001). The standards serve the dual purpose of controlling pollutant release or discharge and of defining the maximum level of a pollutant or condition allowable to protect designated uses of ambient waters. For nutrients, the USEPA hopes to help States establish quantified, numerical criteria for causal variables, such as nitrogen and phosphorus, and response variables, such as chlorophyll $a$ and turbidity. The establishment of these criteria could protect local uses and maintain downstream uses. To adopt these criteria, the USEPA has recommended three possible approaches: (1) develop criteria that reflect local conditions and protect designated uses; (2) adopt the USEPA's guidance water-quality criteria for nutrients; or (3) develop protective criteria using appropriate methods and data. As an example of the third option, Robertson and others (2001) provide an alternative, regional approach to determining nutrient criteria in rivers and streams.

The Massachusetts Department of Environmental Protection (MassDEP) Division of Watershed Management (DWM) is responsible for developing water-quality criteria for nutrients and other water-quality parameters for water bodies throughout the State of Massachusetts. The MassDEP did not feel that the criteria developed by the USEPA for Ecoregions VIII (Nutrient Poor, Largely Glaciated, Upper Midwest and Northeast) and XIV (Eastern Coastal Plain), the ecoregions in which Massachusetts lies, appropriately represented the water-quality conditions in the State (Dennis R. Dunn, Massachusetts Department of Environmental Protection, oral commun., 2006). That is, much of the data included in the USEPA's criteria were obtained from areas where nutrient concentrations were not representative of conditions in Massachusetts, and using those data to derive nutrient criteria would result in concentrations inappropriate for Massachusetts rivers and streams. Therefore, the MassDEP decided to obtain new data that adequately reflected conditions in the State.

The MassDEP DWM is considering the development of not only numerical nutrient criteria, but also an alternative, science-based framework for interpreting narrative criteria for nutrients. These narrative criteria would limit nutrients to concentrations that do not produce noxious conditions (Mark Mattson and Russell Isaac, Massachusetts Department of
Environmental Protection, Division of Watershed Management, written commun., 2006).

The U.S. Geological Survey (USGS), in cooperation with the MassDEP DWM, collected water-quality and ancillary data in 2003 and 2004 for the MassDEP DWM to use in establishing these criteria or in developing a framework for interpreting the narrative criteria. Samples were collected in June, July, August, and September of each year. To avoid effects of storm-runoff high flows, samples were not collected until summer low-flow conditions were re-established after storms.

This report describes the review, synthesis, and assessment of water-quality data collected in 2003 and 2004 by the USGS for the development of nutrient criteria by the MassDEP; data collected by another USGS study in 2001 (Riskin and others, 2003) are also included, as recommended by the USEPA (U.S. Environmental Protection Agency, 2000, 2001). The analyses described in the report were those determined by the MassDEP as being most useful to its efforts to establish nutrient criteria.

Water-quality and related parameters described in this report include the nutrients, phosphorus and nitrogen, periphyton chlorophyll $a$, turbidity, aquatic-plant density, dissolved oxygen concentration, color, and specific conductance. The report also considers yearly differences, the effects of some geographical, or landscape, characteristics on water quality, the presence or absence of upstream licensed dischargers (in general, this refers to wastewater-treatment plants), the degree of canopy openness, and antecedent flow conditions.

Data were from 76 sites distributed throughout the Massachusetts mainland; no sites were chosen on islands, such as Martha's Vineyard or Nantucket. The sites were selected to provide a wide range of representative samples of various types of surface waters, not to obtain a statistical sample. Sixty-five of the sites had unique USGS station identifiers associated with them (fig. 1). At 11 of these locations, there were 2 closely colocated sites, which were differentiated by their extent of canopy openness where one site was described as open canopy and the other as closed canopy; identical USGS station identifiers were used for these sites.

\section{Sampling Sites and Categories}

Sampling sites were selected by the DWM based primarily on prior knowledge and experience from state-wide investigations. Specific sites were included to obtain data representing predetermined categories of data analyses, such as basin area, nutrient ecoregion, canopy openness; the number of sites does not necessarily represent the proportion of streams in each category. Dodds and Welch (2000) recommend that the full range of stream categories be sampled in proportion to their occurrence when developing models for setting nutrient criteria. 


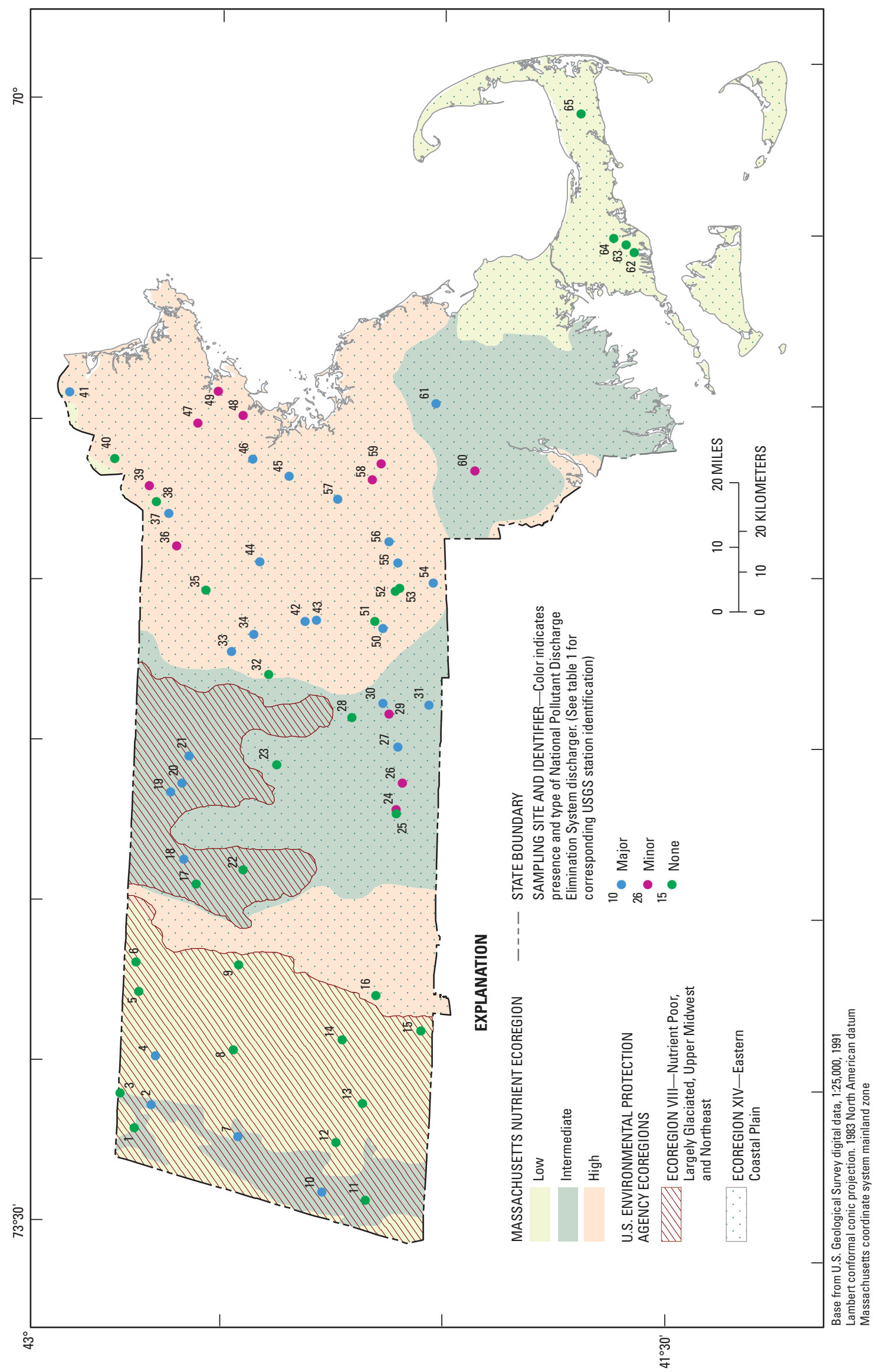

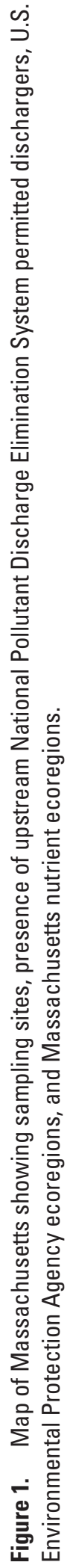




\section{Sampling-Site Selection}

Forty-three streams were selected for sampling by the DWM in 2003, representing free-flowing reaches located in each of three lake-based nutrient ecoregions in Massachusetts (Rohm and others, 1995; fig. 1). The streams included headwater streams, major tributaries, and mainstem rivers (Steven Halterman, Massachusetts Department of Environmental Protection, Division of Watershed Management, written commun., 2006). In order to ensure the inclusion of streams characterized by a wide range of nutrient concentrations and environmental conditions, sampling stations were selected on the basis of historical phosphorus data and field observations of algal blooms or extensive periphyton growth. To minimize the effects of light on periphyton distribution and density wherever possible, closed-canopy sites were preferred for periphyton sampling. Streams in each size category and nutrient ecoregion, with water-quality conditions ranging from near-pristine to highly eutrophic, were represented in the sites selected (fig. 1; table 1).

In order to test the effect of stream shading on nutrientrelated effects, the 2004 sampling design included stations where open and closed canopy sites in close proximity could be sampled (Steven Halterman, Massachusetts Department of Environmental Protection, Division of Watershed Management, written commun., 2006). In addition, 13 sites sampled in 2003 were resampled in 2004 to test for year-toyear differences. To gain insights into variability within 1 sampling season, samples were collected 3 times at 12 stations in 2004.

Data from a 2001 investigation (Riskin and others, 2003) were incorporated to enlarge the water-quality dataset used in this study. In the combined water-quality dataset of data collected for the DWM and the data from the 2001 study, color was the only parameter not in the 2001 data. The study by Riskin and others (2003) selected sites to represent impaired and moderately impaired water-quality conditions and sites for reference. The 12 Massachusetts sampling sites in that study also were used in the 2003 and 2004 field studies; however, the sites are all located in eastern Massachusetts and do not represent conditions throughout the State.

Some of the water-quality data were collected from multiple sites on the same streams: the Assabet River, with three sites, is a tributary to the Concord River, one site; the Charles River, four sites; the Millers River, two sites; the Nashua River, two sites; and the French River, two sites. Furthermore, the East Branch of the Neponset River, with one site, is also a major tributary of the Neponset River, which also has one site. Possible similarities in data from these rivers with multiple sites may weight their effects on the analyses.

\section{Sampling-Site Categories}

Rohm and others (1995) described nutrient ecoregions for the northeastern United States based on measured concentrations of phosphorus in lakes. In Massachusetts, three phosphorus-based nutrient ecoregions were defined, and the DWM used these ecoregions to guide the selection of stream-sampling sites (fig. 1). The high phosphorus-concentration nutrient ecoregion was in the northeastern part of Massachusetts and along the Connecticut River, and the low phosphorus-concentration nutrient ecoregion primarily comprised the southeastern part of the State, including Cape Cod, and the central part of western Massachusetts. The intermediate phosphorus-concentration nutrient ecoregion included the Housatonic River Basin, central Massachusetts east of the Connecticut River, and about half of southeastern Massachusetts. Thirty stations were chosen in the high phosphorus-concentration nutrient ecoregion of the State, 22 stations in the intermediate phosphorus-concentration nutrient ecoregion, and 13 stations in the low phosphorus-concentration nutrient ecoregion. The unequal distribution of sites among the three nutrient ecoregions may have the effect of weighting the data more strongly toward reflecting conditions in the high phosphorus-concentration nutrient ecoregion.

The MassDEP DWM selected basins for sampling ranging in size from watersheds of less than $10 \mathrm{mi}^{2}\left(25.9 \mathrm{~km}^{2}\right)$ (second-order streams, in general), 10 to approximately $100 \mathrm{mi}^{2}$ (25.9 to approximately $259 \mathrm{~km}^{2}$ ) (third- and fourthorder streams, in general), and 100 to approximately $350 \mathrm{mi}^{2}$ (259 to approximately $900 \mathrm{~km}^{2}$ )(fifth order, in general) (Steven Halterman, Massachusetts Department of Environmental Protection, Division of Watershed Management, written commun., 2006). In this study's analyses, the sites were sorted among basins that were divided into 3 size groups: (1) 22 sites with drainage basins less than $10 \mathrm{mi}^{2}$; (2) 31 sites with drainage basins from 10 to $90 \mathrm{mi}^{2}\left(233 \mathrm{~km}^{2}\right)$; and (3) 12 sites with drainage basins from 90 to $350 \mathrm{mi}^{2}$. (As noted above, some of the sites are located in the same basin, a potential source of autocorrelation in the data analyses.) While this distribution of basins may reflect the distribution of stream basins in the State, the small number of large basins may exaggerate differences among the size categories and may affect statistical interpretations of these data.

Twenty-six of the sampling locations are located downstream from major NPDES-permitted dischargers; 25 of these locations are downstream from wastewater-treatment plants and one location is downstream from a nuclear power plant. (Major NPDES-permitted dischargers release more than $1 \mathrm{Mgal} / \mathrm{d}$; minor NPDES-permitted dischargers release less than $1 \mathrm{Mgal} / \mathrm{d}$.) Six of these locations have both open- and 
closed-canopy sampling sites; thus, 42 percent of all sites are downstream from major NPDES dischargers. Eleven locations, including 2 with open- and closed-canopy sites, are downstream from minor NPDES-permitted dischargers, and the remaining 28 locations (including 3 with both open- and closed-canopy sites) have no dischargers in their upstream catchments. Thus, about 57 percent of the sites are downstream from major or minor dischargers. A substantial majority of the NPDES-permitted major and minor dischargers upstream from sampling stations are located in the intermediate- and high-nutrient ecoregions (fig. 1); the numbers of dischargers in these two ecoregions are approximately equal. The low-nutrient ecoregion only has one major NPDESpermitted discharger. Thus, relations between water-quality data in this study and lake-based nutrient ecoregions may be more strongly affected by NPDES-permitted dischargers than by the nutrient ecoregions. Or there may be other explanatory variables, such as population, which were not investigated during this study.

Although USEPA ecoregions (Omernik, 1987) were not used to select sites, they were used to examine data. Massachusetts lies in two of these geographic ecoregions (fig. 1): the Northeastern Coastal Zone (Ecoregion XIV, Eastern Coastal Plain) that covers about 60 percent of the State and the Northeastern Highlands (Ecoregion VIII, Nutrient Poor, Largely Glaciated Upper Midwest and Northeast) that includes the remainder of the State (U.S. Environmental Protection Agency, 2000, 2001). Forty-four sampling stations were in Ecoregion XIV and 21 were in Ecoregion VIII. The unequal distribution of sites, although not part of the original field study design, may weight interpretations toward Ecoregion XIV conditions.

In light of the findings of Riskin and others (2003) that shading affected the concentrations of periphyton chlorophyll $a$, sampling sites were selected in 2004 to include opencanopy sites rather than exclusively choosing closed-canopy sites. Eleven of the stations had both open- and closed-canopy sites, 34 had only closed-canopy sites, and 20 had only opencanopy sites.

\section{Sample Collection and Water-Quality Analyses}

Water-quality sample collection followed USGS guidelines for collecting grab samples (Webb and others, 1999). Because the streams were generally small, shallow, and well-mixed, integrated sampling using equal-width- or equal-depth-increment procedures were not needed. Samples were collected from the centroid of flow in 3-L Teflon bottles. After collection, water-quality samples were processed and stored on ice prior to shipment to the USGS National Water
Quality Laboratory (NWQL) for analysis (Patten and Truitt, 1992, 2000). Samples for determination of turbidity were stored on ice and returned to the USGS Massachusetts-Rhode Island Water Science Center for analysis using a Hach 2100N turbidimeter (Wilde and Gibs, 1998). Water color was determined in the field using a Hach Color Test Kit (Hach Company, 1984; Mark Mattson, Massachusetts Department of Environmental Protection, Division of Watershed Management, written commun., 2003). Field-parameter data (temperature, specific conductance, $\mathrm{pH}$, and dissolved oxygen concentration) were collected with each water-quality sample (Wilde and Gibs, 1998).

Chlorophyll $a$ was measured in samples collected from periphyton attached to submerged rocks (Moulton and others, 2002). Algae from a section of each rock were completely removed by scraping and rinsing, and a foil template was made of the scraped area for use in calculating the area. A $5-\mathrm{mL}$ aliquot of the scraped algae-containing rinsate was filtered. The filter was stored and shipped on dry ice to the NWQL for analysis (Arar and Collins, 1997).

A number of semiquantitative and qualitative observations were made when samples were collected. Stream velocity was visually estimated in ranges of: (1) less than $1 \mathrm{ft} / \mathrm{s}(0.3 \mathrm{~m} / \mathrm{s}) ;(2) 1$ to $3 \mathrm{ft} / \mathrm{s}(0.3$ to $0.9 \mathrm{~m} / \mathrm{s})$; and (3) greater than $3 \mathrm{ft} / \mathrm{s}(0.9 \mathrm{~m} / \mathrm{s})$, following DWM standard procedures for the collection of ancillary information during water-quality sampling. The percentage of open canopy was calculated from measurements made with an inclinometer (Fitzpatrick and others, 1998). The densities (as percentage of streambed substrate covered) of several categories of aquatic plant life were estimated visually in classes defined as not observed (none), sparse ( 1 to 25 percent), moderate ( 26 to 50 percent), dense (51 to 75 percent), and very dense ( 76 to 100 percent). The categories included aquatic plants, filamentous periphyton, periphyton film, periphyton floc, and aquatic moss. While the values reported seem amenable to semiquantitative analysis, the subjective (qualitative) nature of their determination calls for caution in any data interpretation.

During the 2003 and 2004 field studies, 5 field-blank and 13 split-sample-replicate samples were collected for quality control. Blank samples provide information on contamination that may occur during sample processing and affect the resulting data. One blank sample had a single detection (total phosphorus at an estimated concentration of $0.003 \mathrm{mg} / \mathrm{L}$, which is less than the reporting level of $0.004 \mathrm{mg} / \mathrm{L}$ ). Splitsample replicates help define the variability in environmental data associated with sample processing. Relative percent differences (RPD) were calculated for turbidity and for nutrient and chlorophyll $a$ concentrations. Two pairs of turbidity samples and replicates had RPD values that exceeded 10 percent, as did one of the chlorophyll $a$ sample pairs. None of the RPD values for the paired nutrient samples and replicates exceeded 10 percent. 


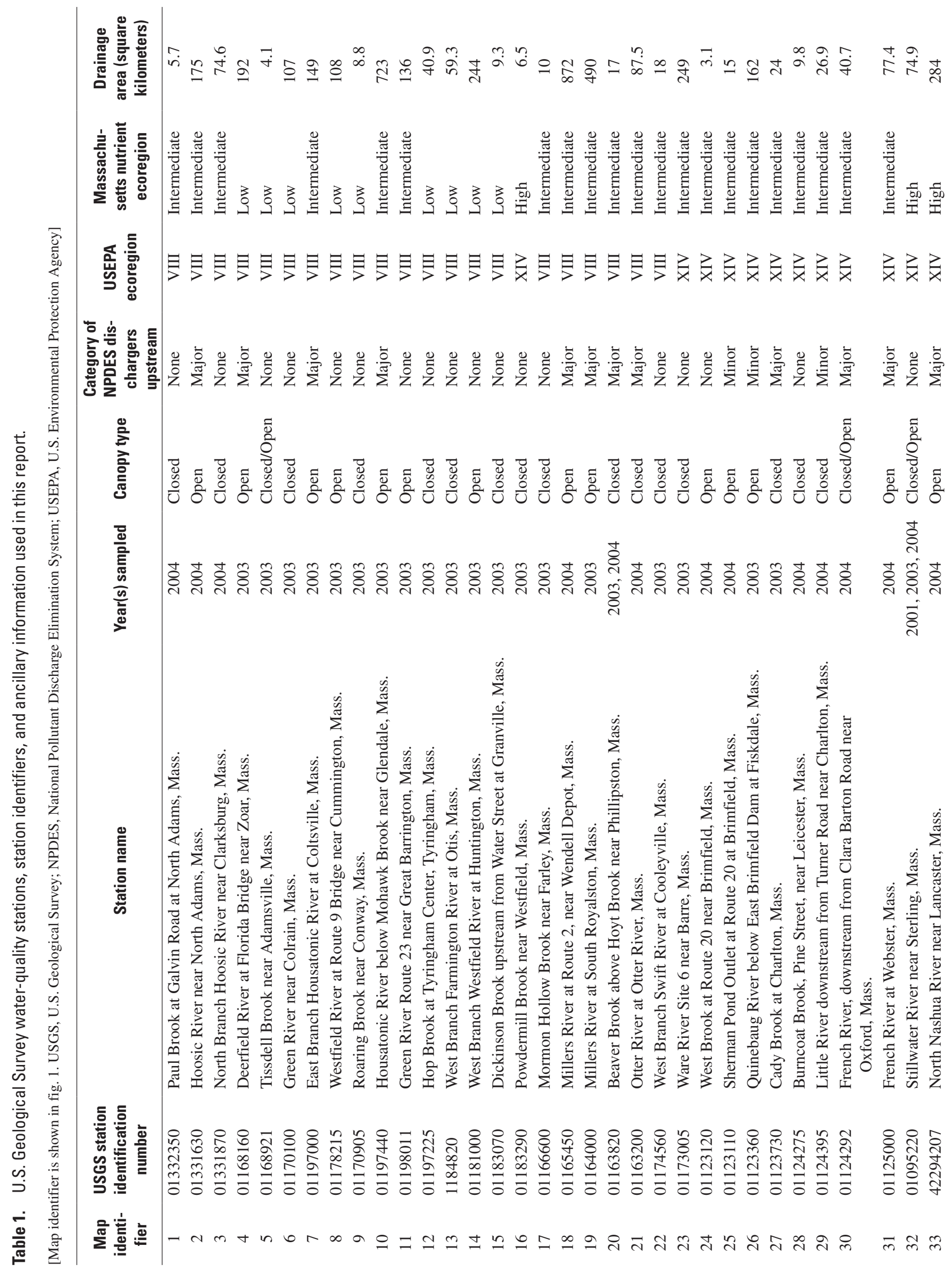




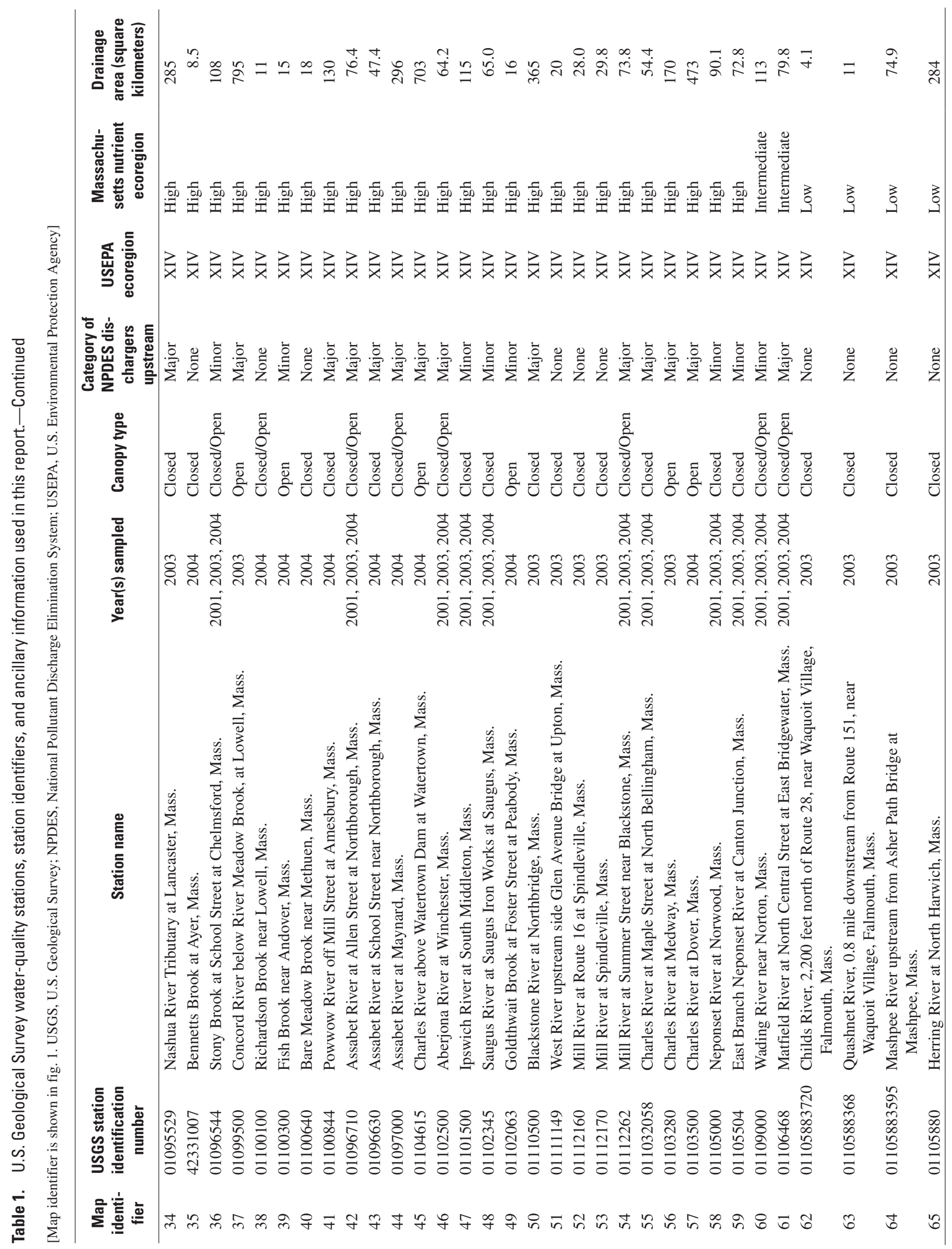




\section{Assessment of Data}

USEPA guidelines recommend the use of all existing data to describe conditions at all sites selected to characterize a State's water quality. To avoid biasing the data analysis and interpretation because of unequal distribution of data among sites, the USEPA further recommends the use of a median value for each parameter at each site. For example, in this study, some sites were sampled five times in 2001, once in 2003 , and three times in 2004, whereas almost all others were sampled only once in 2003 or 2004 . One site was sampled once in both 2003 and 2004 (table 1). Without normalizing the data by using medians for each site, analyses would be biased toward the results of more frequently sampled sites (U.S. Environmental Protection Agency, 2000, 2001). This study used the median values as recommended by the USEPA.

To take account of the effects of seasonal differences in water quality, the USEPA recommends that medians should be determined after separating the data by seasons defined as winter (January through March), spring (April through June), summer (July through September), and fall (October through December). The USEPA recommends the use of either the 25th-percentile value of median concentrations at all sampled sites for setting numerical nutrient criteria when using all available data or the 75th-percentile when only using reference-site data. In this study, neither seasonal data nor extensive reference-site data were available. The existing data were collected from June through September, with few data collected in June; therefore, median values were not differentiated seasonally. When determining distributions of concentrations among groups of data, median values for all data were used. Thus, a 25th-percentile value is actually the 25th percentile of the medians; the median value for all stations is the median of all station medians.

Natural and anthropogenic effects are considered in examining specific factors that may influence water quality. Thus, geographic differences, such as ecoregions and nutrient ecoregions; hydrologic differences, such as stream size and slope and antecedent flow; ecological differences, such as degree of canopy openness; and the presence and size of NPDES-permitted dischargers are included in this report's analyses.

Water-quality samples and field parameter data were only collected once at a sampling station on a sampling date, even if chlorophyll $a$ samples were collected at open- and closedcanopy sites. Therefore, other than the chlorophyll $a$ data, the water-quality data associated with co-located open- and closed-canopy sites on a given date are identical.

The software package used for all graphical and statistical analyses was S-PLUS Professional version 6.1 (Insightful Corp.) Scatter plots, boxplots, and bubble plots were the graphical routines used to visually present the data. In most of these graphs, data were presented as log concentrations because the wide range of concentrations caused by outlier values would otherwise make it difficult to differentiate data points. Statistical analyses used in this study included summary statistics, correlation analysis, the Kruskal-Wallis Rank Sum Test $(\alpha=0.05)$, and linear regression analysis.

Total nitrogen was calculated as the sum of analytical results for nitrate plus nitrite, ammonia, and organic nitrogen. In calculating total nitrogen values in the raw data, there were rare instances of missing data because of analytical results for ammonia that were less than the reporting level. In order to maximize the number of total nitrogen values that could be used in analyses, some substitutions were made for the censored ammonia concentrations. If the ammonia reporting level was less than 20 percent of the other total nitrogen components, then the ammonia reporting level was substituted in the calculation. If the ammonia reporting level was greater than 20 percent, then the total nitrogen value was not calculated, and data were listed as not available (NA) in tables. These approaches were taken to minimize effects on data while adding useful data to the evaluations.

In order to describe the water-quality data that compose the results of this study, several different approaches are taken. These approaches involve splitting the completed dataset into categorical subsets that separate geographic (Massachusetts nutrient ecoregion, for example), environmental (type of upstream NPDES-permitted discharger), and temporal (year-to-year) differences for comparison. Subdividing these categories occasionally created sample sizes that were too small for robust statistical interpretation. Summary statistics are presented to describe the general characteristics of the data within categories. Then, graphical methods were used to enable visual comparisons among the data subsets. Finally, statistical analyses examined whether the distributions of medians among the data subsets differed significantly. Regression and correlation analyses were used to explore causal relations among some of the data.

\section{Characterization of Water-Quality Data}

Water-quality data at stations are characterized by medians (as described previously) that may represent one sample per station or multiple samples per station that were collected during 1,2 , or 3 years. This introduces variability into the dataset (and a different amount of variability per station) that is illustrated by summary statistics of water-quality data by year. Summary data (table 2; fig. 2) synthesizing the yearly median data indicate that the values vary somewhat from year to year but, because the sampling-site selection varied from year to year, inferences drawn from these annual summary data may not be dependable. Specifically, the 2001 data in the table represent medians from 12 stations, whereas 2003 and 2004 data represent more than 30 stations in each year. Another factor affecting comparisons of the variability among the year-to-year data is the absence of stream-discharge data. Measuring discharge was not part of the 2003 and 2004 field studies, and differences in discharge, even under summer low-flow conditions, can cause considerable variations in 
Table 2. Summary statistics for median values of all water-quality parameters measured at sampling stations.

[Parentheses enclose all chlorophyll $a$ values, separating them from closed-canopy chlorophyll $a$ values (not in parentheses). 2001, 2003, and 2004 indicate the years for which medians were determined]

\begin{tabular}{|c|c|c|c|c|c|c|c|c|c|c|}
\hline \multicolumn{5}{|c|}{ CONCENTRATIONS } & \multicolumn{6}{|c|}{ OTHER PARAMETERS } \\
\hline & \multicolumn{4}{|c|}{ Total phosphorus, in milligrams per liter, as $\mathbf{P}$} & \multicolumn{6}{|c|}{ Color, in platinum-cobalt units } \\
\hline & 2001 & 2003 & 2004 & All years & & & 2003 & & 2004 & Both years \\
\hline Minimum & 0.021 & 0.004 & 0.002 & 0.002 & & & 18.6 & & 17 & 18.5 \\
\hline 25th percentile & .037 & .017 & .027 & .019 & & & 37.2 & & 27 & 34.7 \\
\hline Median & .048 & .03 & .043 & .038 & & & 37.2 & & 40 & 37.2 \\
\hline 75th percentile & .06 & .052 & .085 & .065 & & & 55.8 & & 65 & 58 \\
\hline \multirow[t]{3}{*}{ Maximum } & .2 & 1.12 & .51 & 1.12 & & & 112 & & 60 & 160 \\
\hline & \multicolumn{4}{|c|}{ Total nitrogen, in milligrams per liter, as $\mathbf{N}$} & \multicolumn{6}{|c|}{ Turbidity, in nephelometric turbidity units } \\
\hline & 2001 & 2003 & 2004 & All years & 200 & & 2003 & & 2004 & All years \\
\hline Minimum & 0.44 & 0.214 & 0.179 & 0.179 & 1.2 & & 0.29 & & 0.49 & 0.29 \\
\hline 25th percentile & .71 & .369 & 601 & .44 & 2.2 & 75 & .93 & & 1.525 & 1.2 \\
\hline Median & .83 & .598 & .842 & .66 & 3.1 & & 1.35 & & 1.95 & 1.7 \\
\hline 75th percentile & 2.713 & 1.021 & 1.359 & 1.24 & 4.4 & & 2 & & 3.9 & 2.8 \\
\hline \multirow[t]{3}{*}{ Maximum } & 4.15 & 13.96 & 8.4 & 8.32 & 6.8 & & 7.1 & & 10 & 10 \\
\hline & \multicolumn{4}{|c|}{ Total dissolved nitrogen, in milligrams per liter, as $\mathbf{N}$} & \multicolumn{6}{|c|}{$\begin{array}{l}\text { Specific conductance, in microsiemens } \\
\text { per centimeter at } 25^{\circ} \text { Celsius }\end{array}$} \\
\hline & 2001 & 2003 & 2004 & All years & 200 & & 2003 & & 2004 & All years \\
\hline Minimum & 0.12 & 0.034 & 0.052 & 0.034 & 141 & & 25 & & 72 & 25 \\
\hline 25th percentile & .205 & .154 & .171 & .154 & 258.5 & & 110.5 & & 35.25 & 134 \\
\hline Median & .415 & .284 & .336 & .32 & 359 & & 274 & & 46.5 & 277 \\
\hline 75th percentile & 2.183 & .972 & 1.024 & 1.024 & 447.5 & & +26 & & 48.25 & 431 \\
\hline \multirow[t]{3}{*}{ Maximum } & 3.41 & 14.66 & 7.47 & 7.47 & 732 & & 729 & & 21 & 892 \\
\hline & \multicolumn{4}{|c|}{ Dissolved oxygen, in milligrams per liter } & \multicolumn{6}{|c|}{$\mathrm{pH}$, in standard units } \\
\hline & 2001 & 2003 & 2004 & All years & 200 & & 2003 & & 2004 & All years \\
\hline Minimum & 6.3 & 2.8 & 2.1 & 2.1 & 6.6 & & 6 & & 5.9 & 5.9 \\
\hline 25th percentile & 7.25 & 7.55 & 6.7 & 7.3 & 6.7 & 75 & 6.65 & & 6.7 & 6.7 \\
\hline Median & 7.8 & 8.2 & 7.5 & 8.1 & 7.1 & & 7.0 & & 7.0 & 7.0 \\
\hline 75th percentile & 8.475 & 8.7 & 8.2 & 8.7 & 7.4 & 25 & 7.25 & & 7.25 & 7.3 \\
\hline \multirow[t]{2}{*}{ Maximum } & 8.8 & 10.3 & 10.0 & 10.3 & 7.5 & & 8.2 & & 8.7 & 8.7 \\
\hline & \multicolumn{10}{|c|}{ Chlorophyll $a$, in milligrams per square meter } \\
\hline Minimum & 2.8 & $(2.8)$ & 1.9 & (1.9) & 2.4 & $(2.4)$ & & 1.9 & (1.9) & \\
\hline 25th percentile & 4.325 & $(4.725)$ & 8.25 & (8.75) & 6.5 & (7.8) & & 6.0 & (7.2) & \\
\hline Median & 6.1 & $(8.25)$ & 18.65 & (20.05) & 11.7 & (15.3) & & 15.5 & (16.1) & \\
\hline 75th percentile & 13.0125 & (19.425) & 37.5 & $(42.45)$ & 40.3 & (44.625) & & 40.25 & $(40.8$ & \\
\hline Maximum & 43.2 & (101) & 216 & (216) & 85.5 & (322) & & 216 & (216) & \\
\hline
\end{tabular}



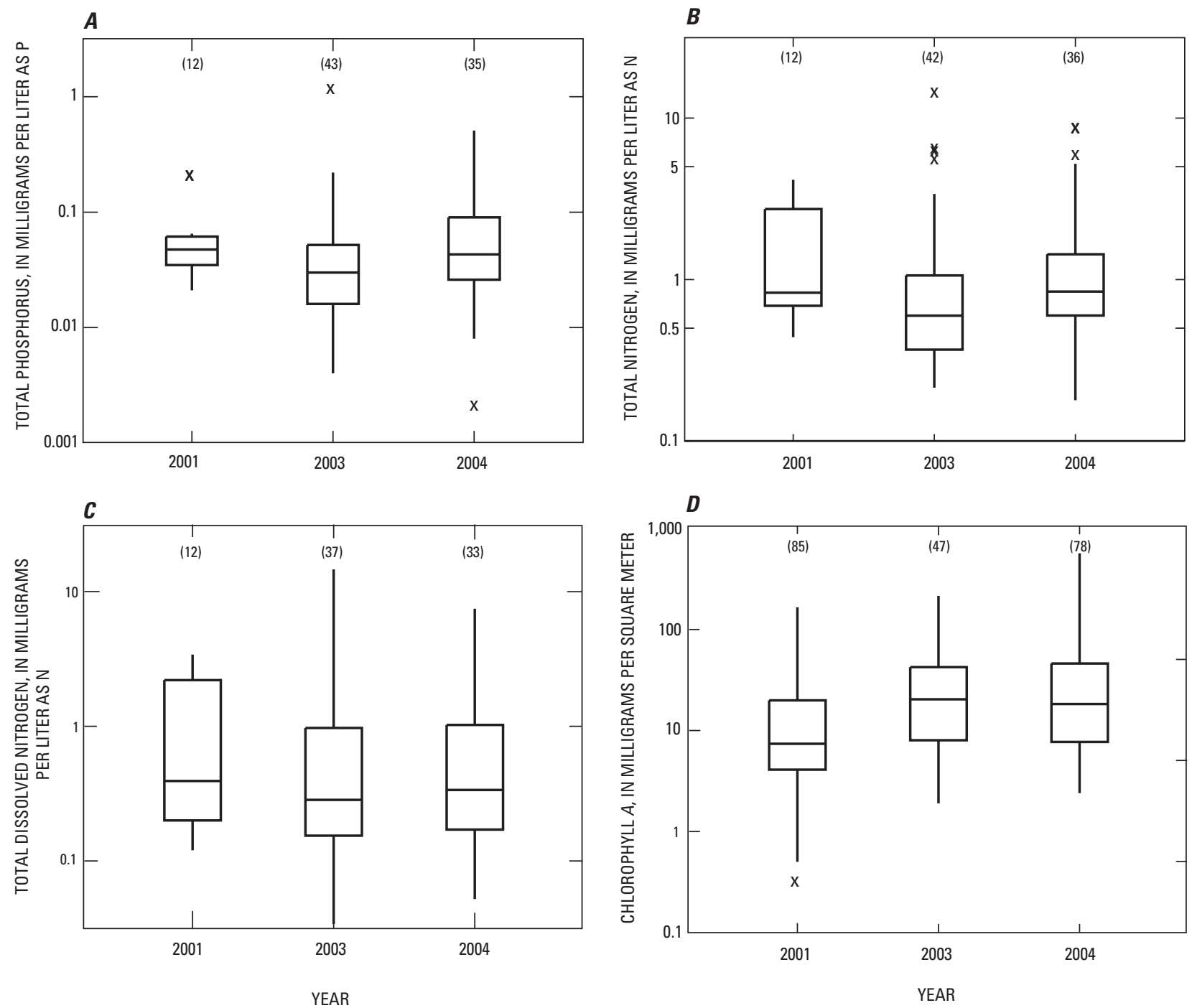

\section{EXPLANATION}

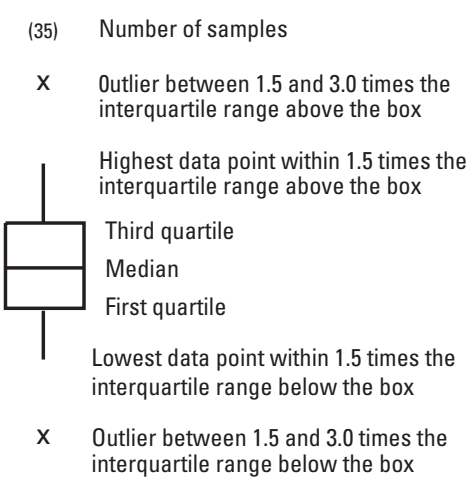

Figure 2. Distribution of median $(A)$ total phosphorus, $(B)$ total nitrogen, $(C)$ total dissolved nitrogen, and $(D)$ chlorophyll $a$ concentrations at all sampling sites by year in Massachusetts. $N$, nitrogen; $P$, phosphorus. 

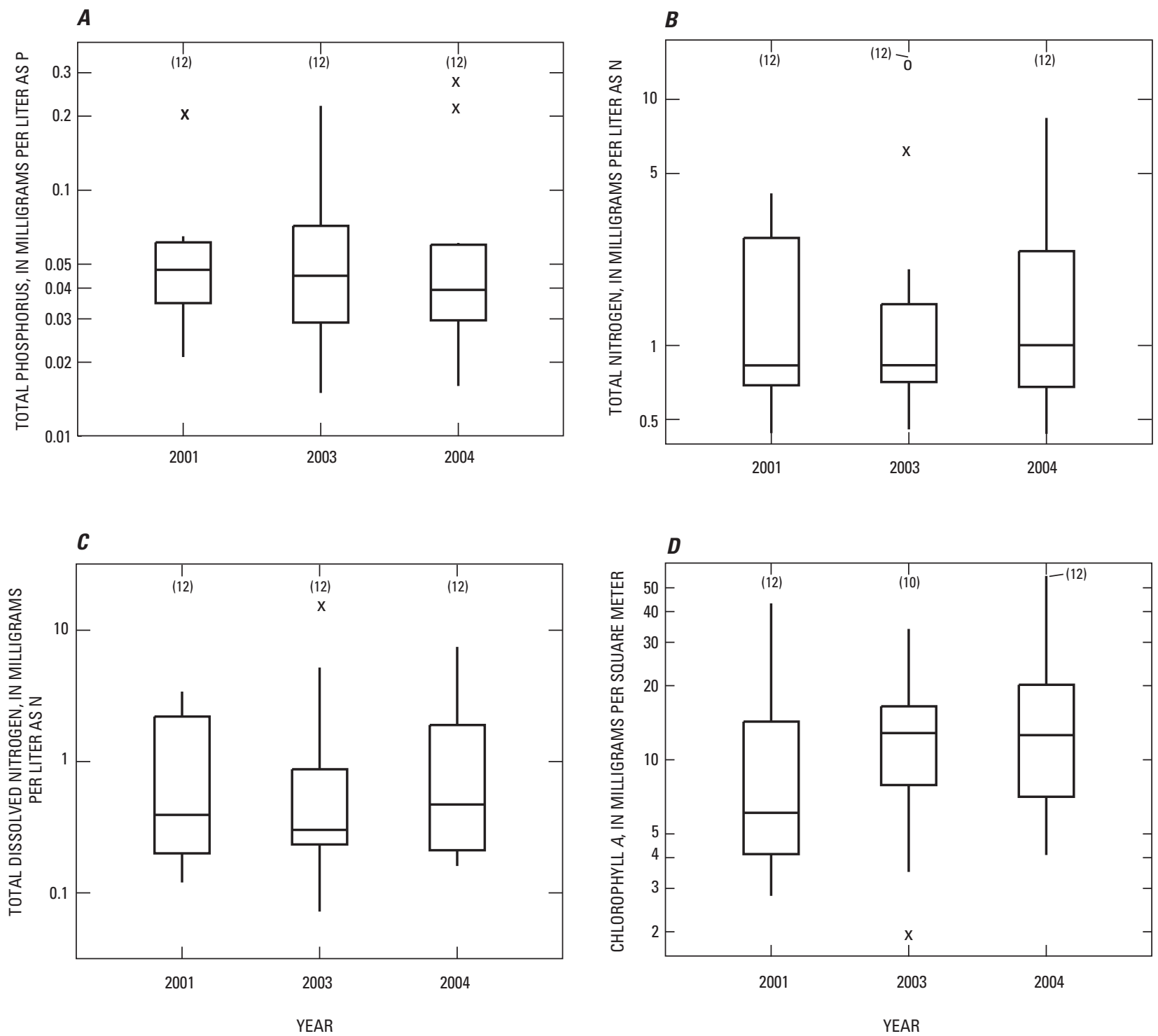

EXPLANATION

(12) Number of samples

$0 \quad$ Outlier greater than 3.0 times the interquartile range above the box

$\mathrm{X} \quad$ Outlier between 1.5 and 3.0 times the interquartile range above the box

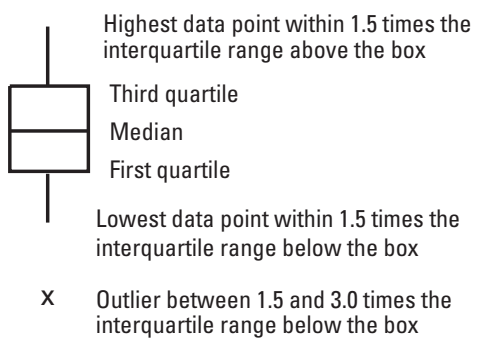

Figure 3. Distribution of median $(A)$ total phosphorus, $(B)$ total nitrogen, $(C)$ total dissolved nitrogen, and $(D)$ chlorophyll $a$ concentrations at 12 sampling sites by year in Massachusetts. 


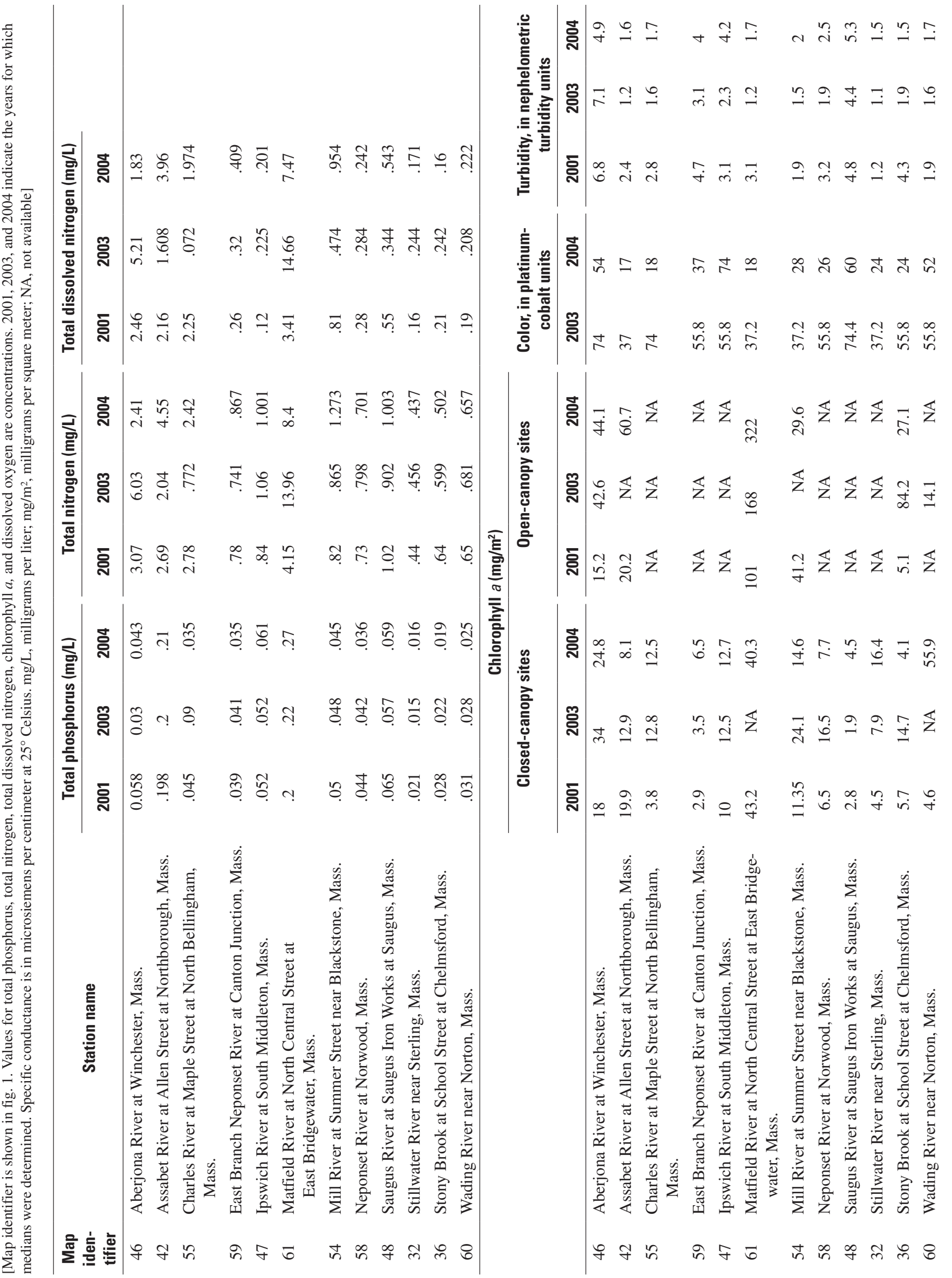




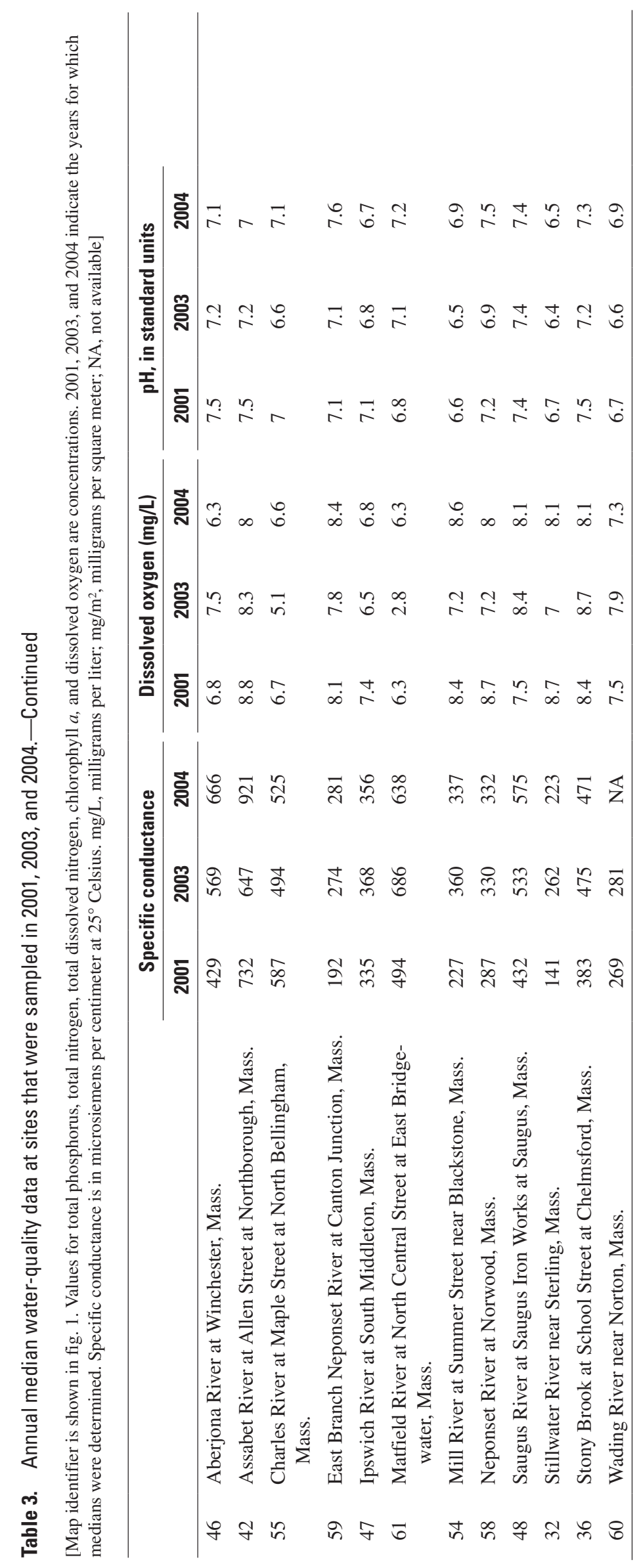


concentrations due to dilution effects. Comparisons based on geographical and hydrological differences may prove more meaningful than yearly differences. Also, a general overview of the values for individual parameters should be useful for understanding sources of data variability. The 25 th-percentile values for all Massachusetts stream data in this study are $0.019 \mathrm{mg} / \mathrm{L}$ for total phosphorus, $0.44 \mathrm{mg} / \mathrm{L}$ for total nitrogen and 1.2 NTU for turbidity (table 2).

While comparisons of the variability among the medians for the 12 stations for which there are 3 years of collected data (table 3; fig. 3) may be more valid on the basis of consistent use of stations than comparisons among the varying array of all stations sampled, the differences in numbers of samples and the uncertain stream-discharge conditions among years for the 12 stations are possible causes for the changing values from year to year (for example, figs. 2 and 3). Some of the values for the stations sampled in 2001, 2003, and 2004 may remain approximately the same over the 3 years (total phosphorus at a number of stations, for example), and others may have a high value as great as 30 times the low value (total dissolved nitrogen at the Charles River at Maple Street at North Bellingham, Mass.). Using medians for all years combined to represent individual stations may minimize datavariability issues associated with those stations; however, most of the stations have only one sampling date that provides the representative data, and that circumstance probably contributes to data variability among the stations.

\section{Nutrients and Turbidity}

USEPA standards relevant to this study are limited to total phosphorus, total nitrogen, and turbidity (U.S. Environmental Protection Agency, 2000, 2001). The USEPA provides values for phytoplankton, but not for periphyton chlorophyll $a$. On the basis of the 25th percentile of concentration data from reference sites aggregated by ecoregion, the USEPA established recommended water-quality critera for total phosphorus, total nitrogen, and turbidity for the two ecoregions in Massachusetts. For Ecoregion VIII (western Massachusetts), the USEPA values are $0.010 \mathrm{mg} / \mathrm{L}$ for total phosphorus, $0.380 \mathrm{mg} / \mathrm{L}$ for total nitrogen, and 0.81 for turbidity. For Ecoregion XIV (eastern Massachusetts), the cor- responding values are $0.031 \mathrm{mg} / \mathrm{L}$ for total phosphorus, 0.710 $\mathrm{mg} / \mathrm{L}$ for total nitrogen, and 1.94 NTU for turbidity.

These values were compared to the 25 th-percentile values from this study for the ecoregions (table 4; figs. 4A and 4B). The 25th-percentile values for Ecoregion VIII are $0.009 \mathrm{mg} / \mathrm{L}$ for total phosphorus, $0.289 \mathrm{mg} / \mathrm{L}$ for total nitrogen, and 1.7 NTU for turbidity. The 25th-percentile values for Ecoregion XIV are $0.028 \mathrm{mg} / \mathrm{L}$ for total phosphorus, $0.583 \mathrm{mg} / \mathrm{L}$ for total nitrogen, and $3.1 \mathrm{NTU}$ for turbidity. Thus, on the basis of samples collected for this study, the 25th-percentile values for median total phosphorus and total nitrogen concentrations are less than the USEPA values for both ecoregions, and the 25th-percentile values for median turbidity exceeded the USEPA values for both ecoregions.

The 25th-percentile values for these three constituents also were examined by Massachusetts nutrient ecoregion (table 4; figs. 5A and 5B). The 25th-percentile values for the Massachusetts low-nutrient ecoregion are $0.011 \mathrm{mg} / \mathrm{L}$ for total phosphorus, $0.289 \mathrm{mg} / \mathrm{L}$ for total nitrogen, and $0.7 \mathrm{NTU}$ for turbidity. The 25th-percentile values for the Massachusetts intermediate-nutrient ecoregion are $0.016 \mathrm{mg} / \mathrm{L}$ for total phosphorus, $0.419 \mathrm{mg} / \mathrm{L}$ for total nitrogen, and $1.1 \mathrm{NTU}$ for turbidity. The 25th-percentile values for the Massachusetts high-nutrient ecoregion are $0.030 \mathrm{mg} / \mathrm{L}$ for total phosphorus, $0.642 \mathrm{mg} / \mathrm{L}$ for total nitrogen, and $1.5 \mathrm{NTU}$ for turbidity.

As would be expected from the field studies designed to analyze a variety of stream-water-quality conditions, the ranges of nutrient concentrations were wide (table 5). Total phosphorus ranged from $0.002 \mathrm{mg} / \mathrm{L}$ (North Branch Hoosic River near Clarksburg, Mass.) to 1,120 mg/L (Blackstone River at Northbridge, Mass.). Total dissolved nitrogen ranged from $0.034 \mathrm{mg} / \mathrm{L}$ (West Branch Swift River at Cooleyville, Mass.) to $7.47 \mathrm{mg} / \mathrm{L}$ (Assabet River at School Street near Northborough, Mass.); total nitrogen ranged from $0.179 \mathrm{mg} / \mathrm{L}$ (North Branch Hoosic River near Clarksburg, Mass.) to $8.32 \mathrm{mg} / \mathrm{L}$ (Assabet River at School Street near Northborough, Mass.).

Turbidity readings were generally quite low. The highest value was 10 NTU (at the Sherman Pond Outlet at Route 20 at Brimfield, Mass.) and the lowest value was 0.29 (at Green River Rt. 23 near Great Barrington, Mass.).

Table 4. The twenty-fifth-percentile values for total phosphorus and total nitrogen concentrations and turbidity measured in U.S. Environmental Protection Agency ecoregions compared to values measured in this study and in Massachusetts low-, intermediate-, and high-nutrient ecoregions.

[USEPA, U.S. Environmental Protection Agency; mg/L, milligrams per liter; NTU, nephelometric turbidity units]

\begin{tabular}{|c|c|c|c|c|c|c|c|}
\hline \multirow[b]{2}{*}{ Constituent } & \multicolumn{2}{|c|}{ ECOREGION VIII } & \multicolumn{2}{|c|}{ ECOREGION XIV } & \multicolumn{3}{|c|}{ Massachusetts nutrient ecoregior } \\
\hline & USEPA & This Study & USEPA & This Study & Low & $\begin{array}{l}\text { Intermedi- } \\
\text { ate }\end{array}$ & High \\
\hline Total phosphorus (mg/L) & 0.010 & 0.009 & 0.031 & 0.028 & 0.011 & 0.016 & 0.030 \\
\hline Total nitrogen (mg/L) & .380 & .289 & .710 & .583 & .289 & .419 & .642 \\
\hline Turbidity (NTU) & .81 & 1.7 & 1.94 & 3.1 & .7 & 1.1 & 1.5 \\
\hline
\end{tabular}



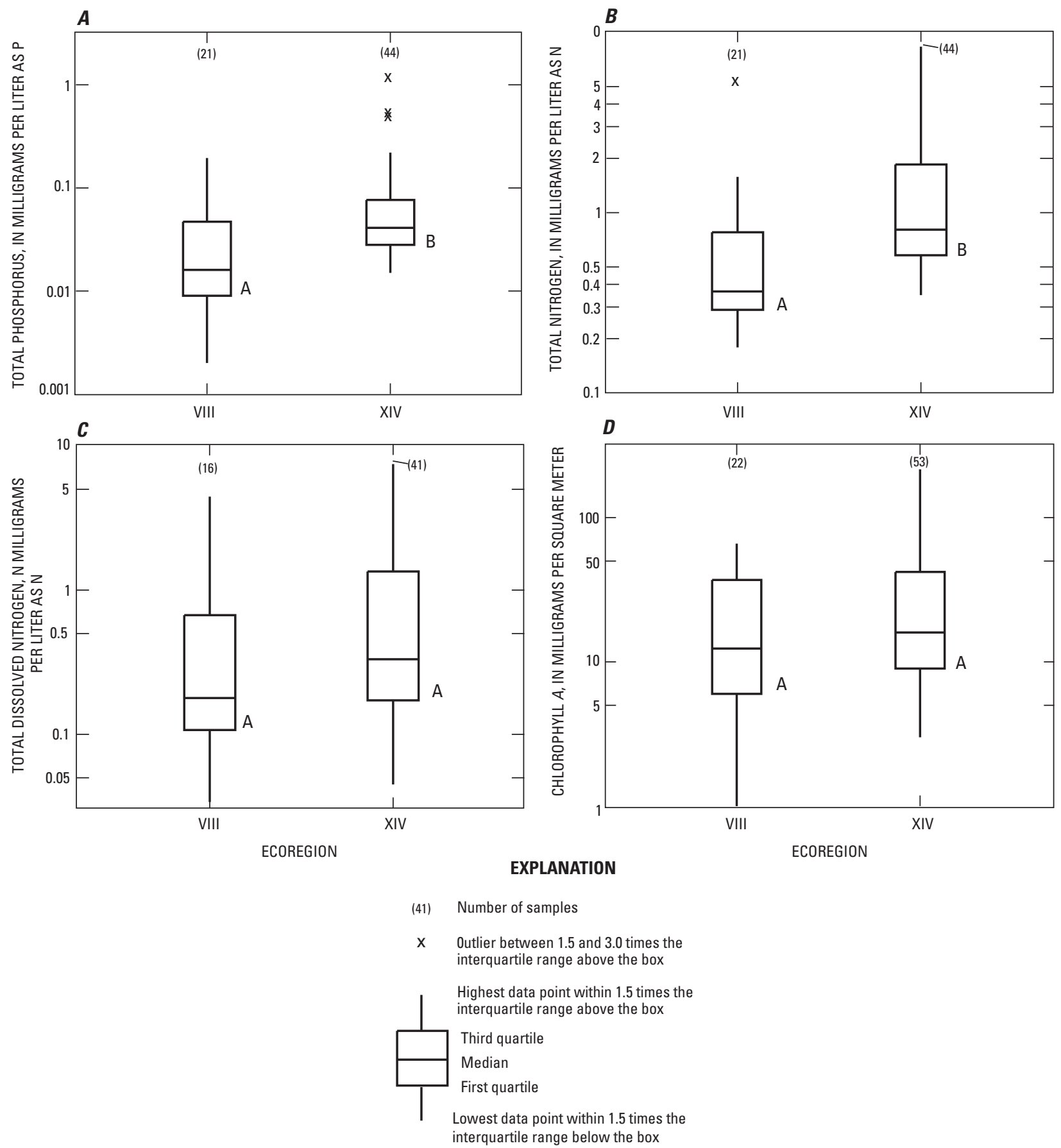

Figure 4. Distribution of median $(A)$ total phosphorus, $(B)$ total nitrogen, $(C)$ total dissolved nitrogen, and $(D)$ chlorophyll $a$ concentrations at all sampling sites by ecoregion in Massachusetts. The results of the Kruskal-Wallis rank sum test are represented as letters. Distributions of groups of data with at least one letter in common do not differ significantly. 

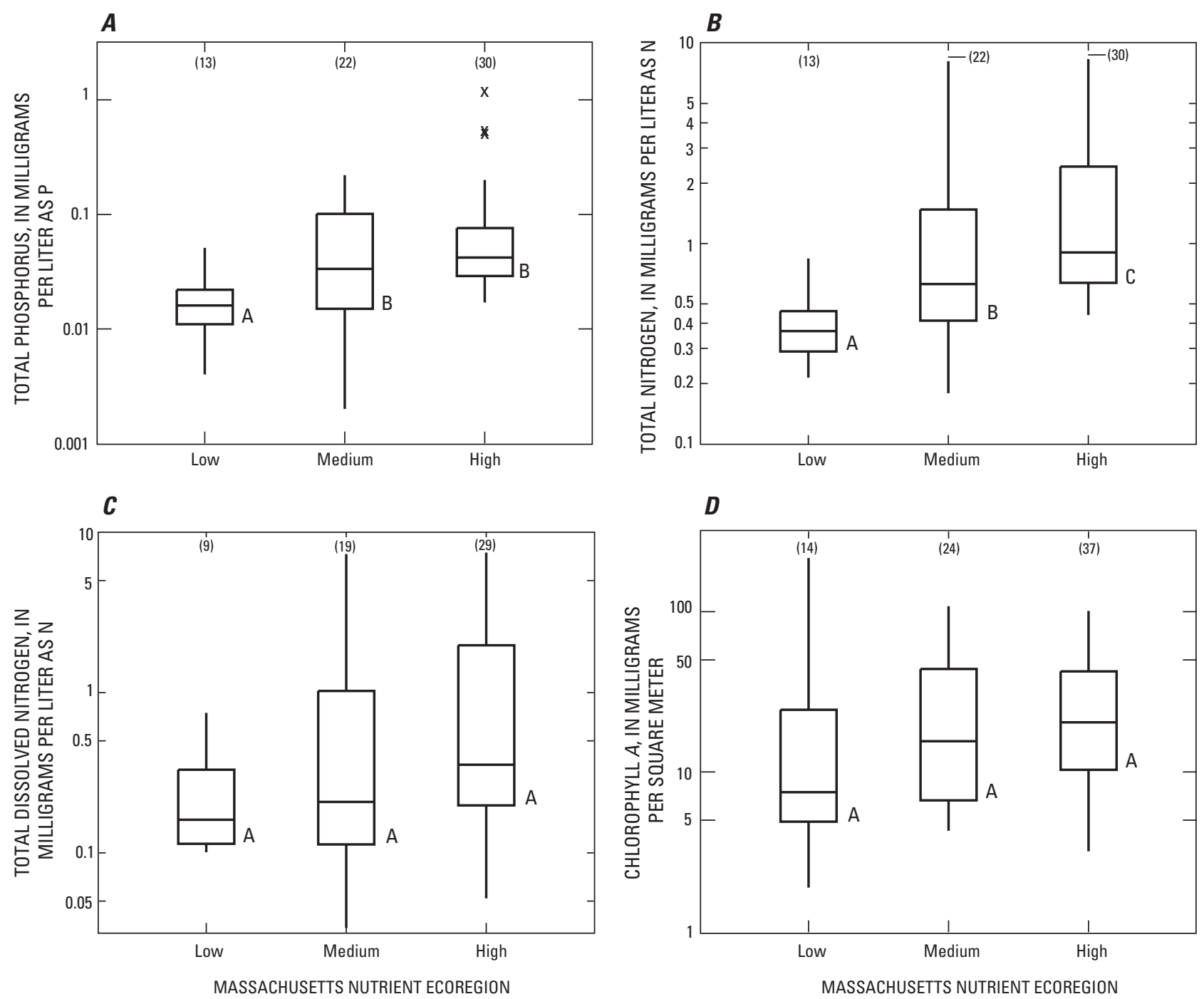

EXPLANATION

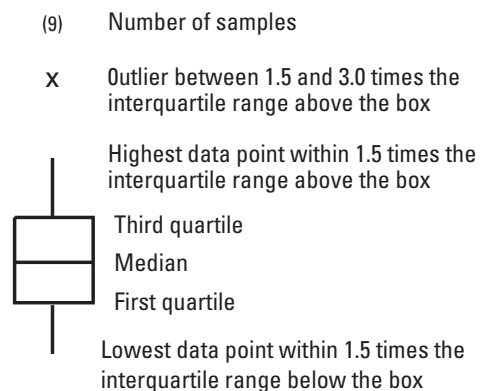

Figure 5. Distribution of median $(A)$ total phosphorus, $(B)$ total nitrogen, $(C)$ total dissolved nitrogen, and $(D)$ chlorophyll $a$ concentrations at all sampling sites by Massachusetts nutrient ecoregion. The results of the Kruskal-Wallis rank sum test are represented as letters. Distributions of groups of data with at least one letter in common do not differ significantly. 


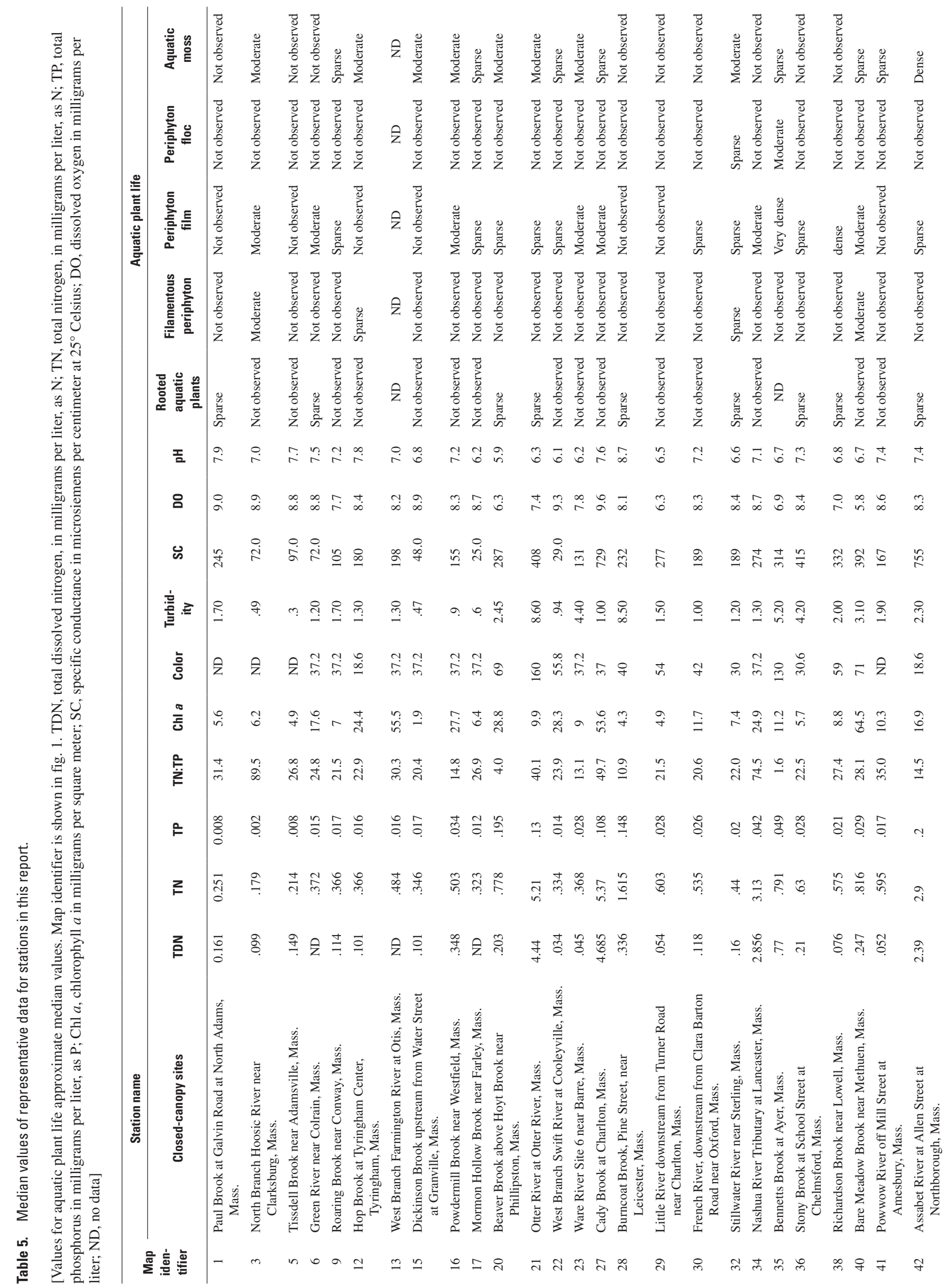




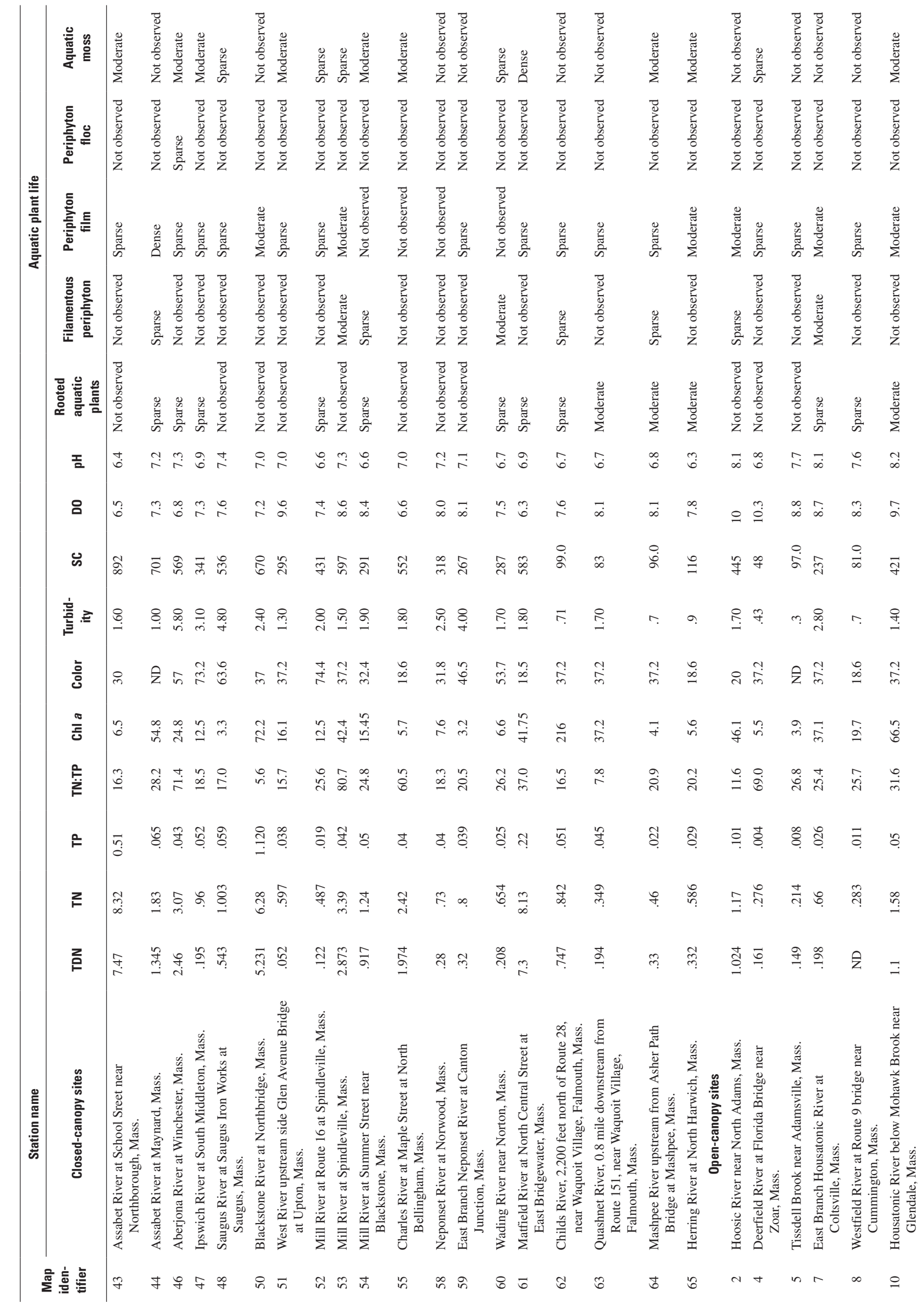




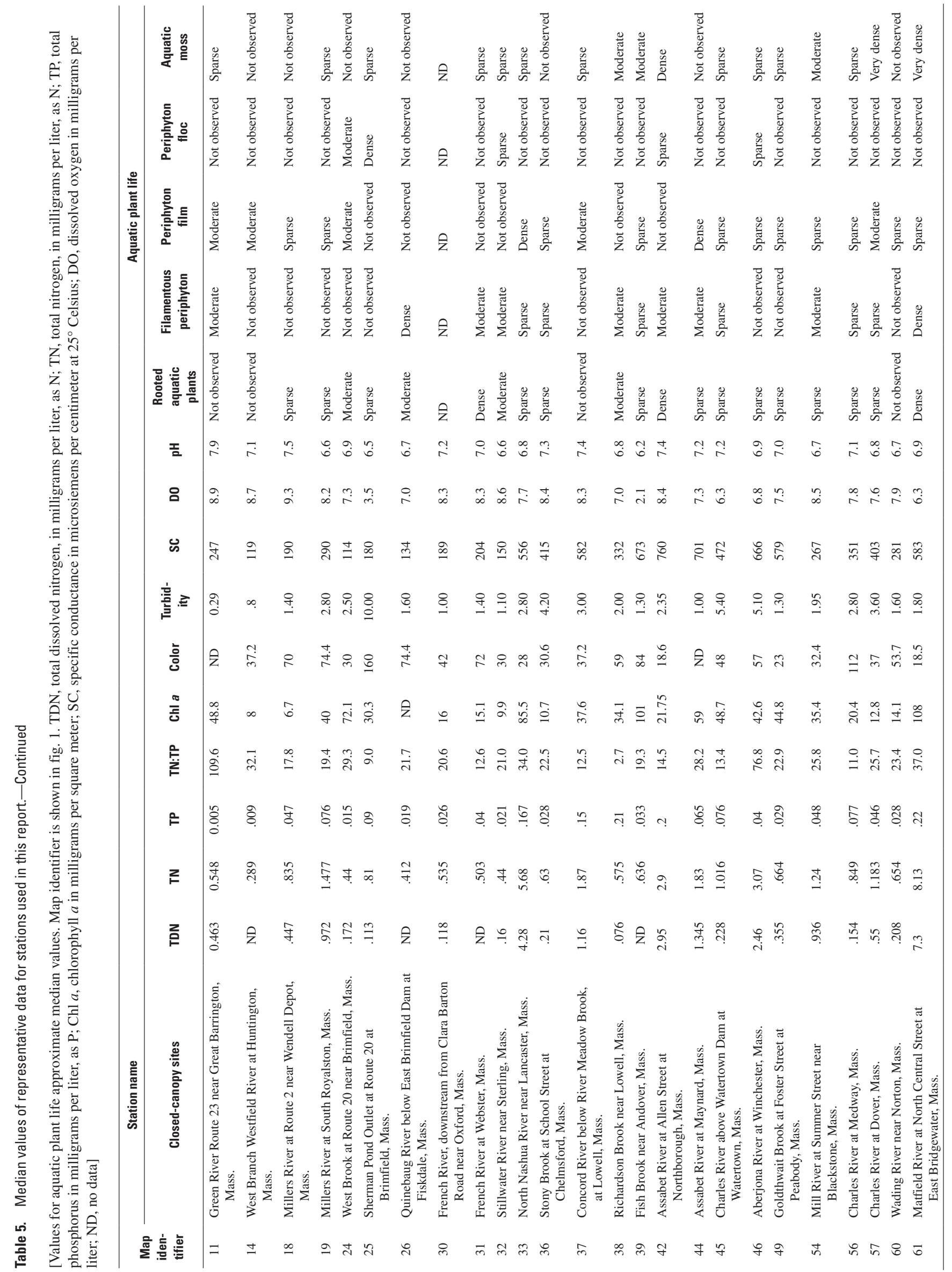




\section{Color}

Median color values ranged from 18.5 to 160 platinum-cobalt units (PCU), with an overall median of 37.2 PCU, for the 2003 and 2004 data (table 2). The DWM has suggested that $70 \mathrm{PCU}$ may be the value used in the future to differentiate colored from clear water (Mark Mattson, Massachusetts Department of Environmental Protection, Division of Watershed Management, written commun., 2006). On the basis of median color values, 12 stations had waters that equaled or exceeded the 70-PCU criterion (table 5). The USEPA did not include color as a characteristic nutrient criterion, but in the future it could be a factor considered by the State in aquatic-use criteria.

\section{Field Parameters}

The field parameters of dissolved oxygen and $\mathrm{pH}$ can reflect local watershed conditions, but they also can change considerably during the day at any given site. Variations among these parameters, therefore, may not be directly linked to nutrient conditions in streams. For example, dissolved oxygen concentration varies with temperature and may drop below the saturation level if the amount of organic matter being oxidized is sufficient; dissolved oxygen concentrations also can rise above saturation level when photosynthesis releases oxygen. Photosynthesis can also cause $\mathrm{pH}$ to vary. Elevated specific conductance may indicate upstream wastewater releases or the presence of salts from urban runoff.

Dissolved oxygen values for all data ranged from 2.1 to $10.3 \mathrm{mg} / \mathrm{L}$ with a median of $8.1 \mathrm{mg} / \mathrm{L}$ (table 2). The lowest $\mathrm{pH}$ value was 5.9 and the highest was 8.7 with an overall median of 7.0. Specific conductance ranged from 25 to $892 \mu \mathrm{S} / \mathrm{cm}$ at $25^{\circ} \mathrm{C}$, with a median of $277 \mu \mathrm{S} / \mathrm{cm}$ at $25^{\circ} \mathrm{C}$; the minimum value is indicative of a reference site (Mormon Hollow Brook; map identifier number 17), and the maximum value represents the conditions at an Assabet River site (map-identifier number 43) downstream from a wastewatertreatment plant (table 5).

\section{Chlorophyll a Concentrations and Plant Densities}

Concentrations of chlorophyll $a$ and plant densities are presumed to reflect nutrient concentrations in surface water, light conditions, topography, and hydrology. Dodds and Welch (2000) did not find any published reports relating water-column nutrient concentrations and macrophyte biomass; the authors further noted that macrophytes can derive nutrition from sediments, and therefore do not rely on surface water to supply nutrients. Relations between nutrients and benthic algal biomass were found to be weak. In this study, concentrations and densities vary widely (table 5). The highest chlorophyll $a$ concentration, $216 \mathrm{mg} / \mathrm{m}^{2}$, was found at the Childs River (map-identifier number 62), and the lowest concentration, $1.9 \mathrm{mg} / \mathrm{m}^{2}$, was found at Dickinson Brook (map-identifier number 15). As stated previously, the visual determination of levels of plant density provides subjective, semiquantitative data that do not yield to simple interpretation; additionally, there are large numbers of "not observed" values. For example, periphyton floc was observed too rarely to make any interpretation about its occurrence.

\section{Categorical Descriptions of Data}

In order to consider the effects of geographic (landscape), anthropogenic, and other natural factors on water quality, data were sorted into a number of categories. These categories include large areal considerations such as USEPA ecoregion, Massachusetts nutrient ecoregion, drainage-basin size, and site-specific considerations such as the presence of upstream wastewater dischargers, and canopy openness. The number of categories and sub-categories occasionally resulted in small sample sizes for statistical interpretation.

\section{U.S. Environmental Protection Agency Ecoregions}

According to the USEPA's ecoregion descriptions, Massachusetts is a part of two of the 14 National ecoregions: the western part of the State is in the Nutrient Poor, Largely Glaciated Upper Midwest and Northeast (Ecoregion VIII), and the eastern part of the State is in the Eastern Coastal Plain (Ecoregion XIV, fig. 1). The median values for total phosphorus, total nitrogen, and total dissolved nitrogen are higher in Ecoregion XIV than in Ecoregion VIII; however, the values for total dissolved nitrogen are almost the same in the two Ecoregions (fig. 4). With many of the Ecoregion XIV stations located in the Massachusetts high-nutrient ecoregion and downstream from major and minor dischargers, these differences are not unexpected. Chlorophyll $a$ concentrations in the two ecoregions are similar and do not reflect the differences in the median nutrient concentrations (fig. 4D).

\section{Drainage-Basin Size}

Drainage-basin size, in square miles, possibly has an effect on water-quality conditions. Larger basins are assumed to have higher nutrient concentrations than smaller basins because the water quality of the larger basins probably is affected by larger cities and wastewater-treatment plant effluent. The data seem to support this assumption. Streams with the largest drainage basin areas (greater than $90 \mathrm{mi}^{2}$ ) have 
higher nutrient concentrations than the basins smaller than 90 $\mathrm{mi}^{2}$, which are characterized by approximately equal nutrient concentrations (fig. 6). Periphyton chlorophyll $a$ concentrations, in contrast, do not necessarily increase with increasing basin area. Some of the relatively small numbers of sampling sites in basins larger than $90 \mathrm{mi}^{2}$ are on the same river, however, which may affect how well the dataset represents these large rivers statewide.

\section{Massachusetts Nutrient Ecoregions}

Relatively high nutrient concentrations at sites sampled in this study that were located in the Massachusetts high-nutrient ecoregion indicate that the lake-based phosphorus nutrient ecoregions are consistent with stream-water nutrient concentrations. The median total concentration in the high-nutrient ecoregion is the highest, but is only slightly higher than in the intermediate-nutrient ecoregion. Median dissolved nitrogen concentrations show a similar pattern, and median total nitrogen concentrations seem to show the clearest differences among the three Massachusetts nutrient ecoregions. However, the interquartile ranges for the intermediate- and high-nutrient ecoregions overlap considerably, suggesting that these two nutrient ecoregions do not differ much. Median chlorophyll $a$ concentrations follow the trend of increasing concentration with nutrient ecoregion, but the medians and interquartile ranges for the intermediate- and high-nutrient ecoregions are almost identical. The unequal distribution of sites among ecoregions and the high proportion of major and minor dischargers in the intermediate- and high-nutrient ecoregions may affect the interpretations of the nutrient and chlorophyll $a$ data, however.

\section{Effects of Dischargers on Water Quality}

In Massachusetts, with numerous small towns and cities distributed throughout the state, many streams serve as receiving waters for much of the treated wastewater. Because 26 of the sampling stations in this study are downstream from major NPDES-permitted dischargers and an additional 11 are downstream from minor NPDES-permitted dischargers, it is expected that the effluent from these facilities would have a substantial effect on the downstream nutrient concentrations. The median concentrations of total phosphorus and total nitrogen demonstrate that the presence of dischargers increases nutrient concentrations (fig. 7, at end of report). The trend in median dissolved nitrogen concentrations is similar; however, the interquartile ranges overlap more than for total phosphorus or total nitrogen. The median periphyton chlorophyll $a$ concentration is highest downstream from major NPDES-permitted dischargers but interquartile ranges and all data, in general, overlap.

\section{Canopy Openness}

Riskin and others (2003) found higher periphyton chlorophyll $a$ concentrations in samples collected from open-canopy sites than from closed-canopy sites at the same sampling locations when the sites were sorted among three categories of nutrient impairment, or enrichment. When comparing the distribution of periphyton chlorophyll $a$ concentrations across the Massachusetts nutrient ecoregions used in this study (fig. 5D), the interquartile ranges of the medians are similar (not significantly different), but the median chlorophyll $a$ concentration for the low-nutrient ecoregion is lower than the other two nutrient ecoregions. If these same data are divided into open- or closed-canopy categories, the chlorophyll $a$ concentration boxplots are similar for closed-canopy sites among the three nutrient ecoregions

(fig. 8, at end of report). For the open-canopy sites, the median chlorophyll $a$ concentrations (approximately $40 \mathrm{mg} / \mathrm{m}^{2}$ ) in the intermediate- and high-nutrient ecoregions are higher than in the low-nutrient ecoregion (approximately $7 \mathrm{mg} / \mathrm{m}^{2}$ ) and higher than the median chlorophyll $a$ concentrations at closed-canopy sites (approximately $10 \mathrm{mg} / \mathrm{m}^{2}$ ). Only four open-canopy sites are in the low-nutrient ecoregion; however, four may be too small a number for drawing inferences.

Median chlorophyll $a$ values at open- and closed-canopy sites do not differ substantially between Ecoregions VIII and XIV. The open-canopy sites do exhibit approximately 4 times higher median values than the closed-canopy sites overall (fig. 9, at end of report).

When closed-canopy sites are compared based on basin size, the median chlorophyll $a$ concentration is highest in the largest basins (greater than $90 \mathrm{mi}^{2}$ ) at closed-canopy sites (fig. 10, at end of report), but only four basins are included in that class. The median chlorophyll $a$ concentrations open- and closed-canopy sites in basins larger than $90 \mathrm{mi}^{2}$ are about the same. In basins smaller than $90 \mathrm{mi}^{2}$, the closed-canopy sites have lower median chlorophyll $a$ concentrations than the opencanopy sites. For open-canopy sites, basins larger than $90 \mathrm{mi}^{2}$ and basins smaller than $10 \mathrm{mi}^{2}$ have approximately the same median chlorophyll $a$ concentrations. Physical factors, such as water depth and turbidity, likely greater in basins larger than $90 \mathrm{mi}^{2}$ than in smaller basins, probably influence light penetration and may have site-specific effects on periphyton growth.

Among the sites downstream from NPDES-permitted dischargers, the differences between open- and closed-canopy sites are not substantial. The only exception is in the minor discharger category where open-canopy sites have a higher chlorophyll $a$ median concentration than closed-canopy sites (fig. 11, at end of report). The numbers of sites in each category, however, are unequal and this distribution of sites may affect the interpretation of the data. 

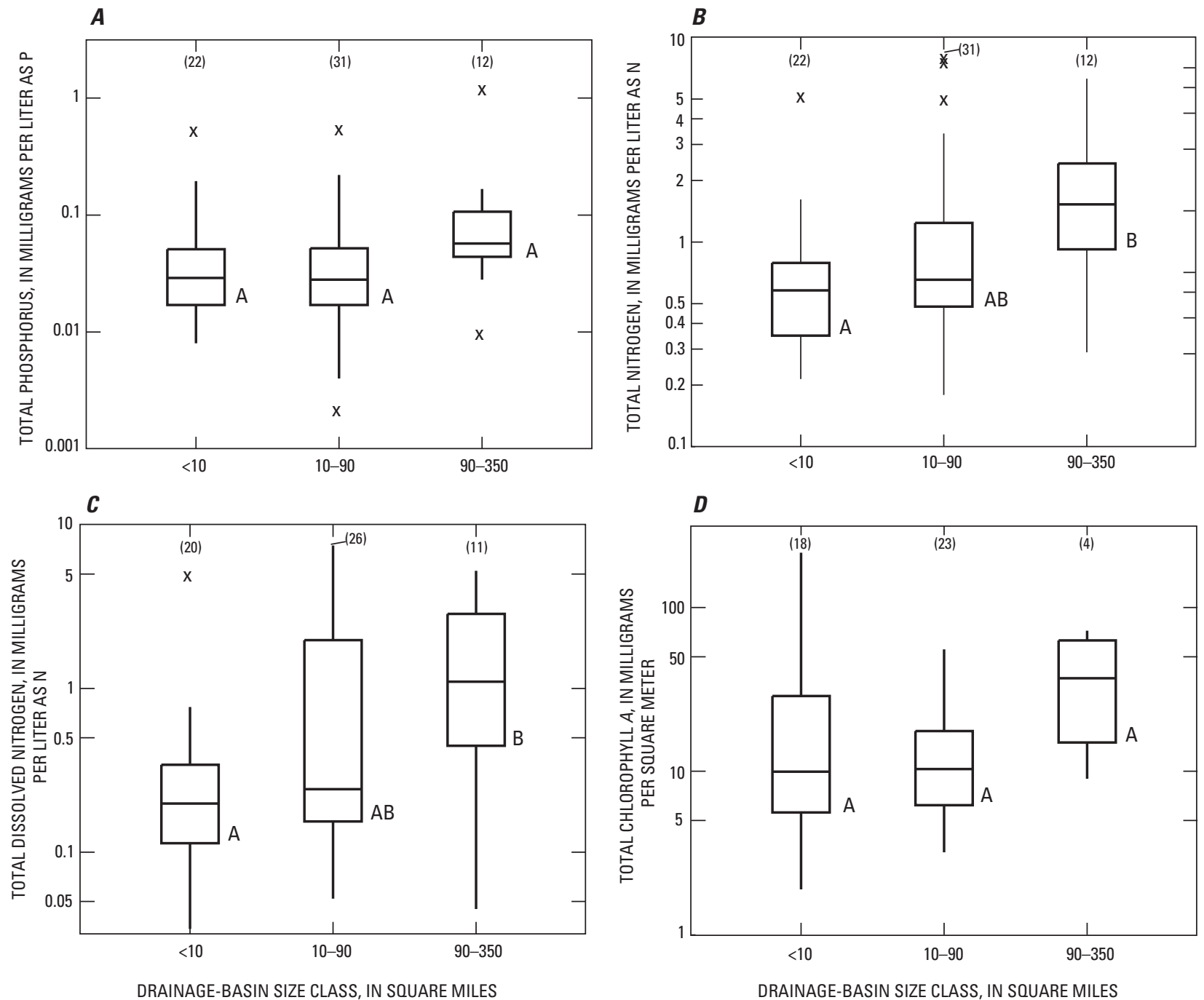

DRAINAGE-BASIN SIZE CLASS, IN SQUARE MILES

EXPLANATION

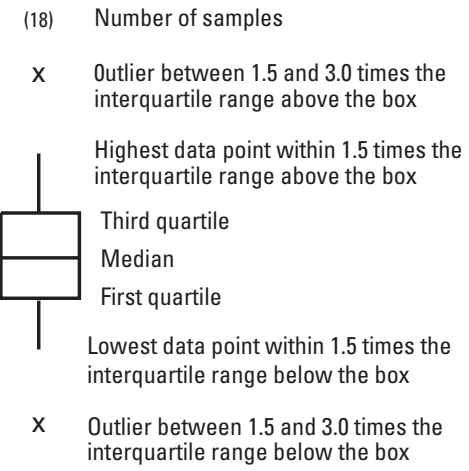

Figure 6. Distribution of median $(A)$ total phosphorus, $(B)$ total nitrogen, $(C)$ total dissolved nitrogen, and $(D)$ chlorophyll $a$ concentrations at all sampling sites by drainage-basin size class in Massachusetts. The results of the Kruskal-Wallis rank sum test are represented as letters. Distributions of groups of data with at least one letter in common do not differ significantly. 
The effect of canopy openness on plant-density data was evaluated in conjunction with the relations of plant density and nutrient concentrations (figs. 12 and 13, at end of report). Strong relations are not apparent. As stated previously, however, the observed plant-density data are subjective and do not seem to be related to nutrient concentrations. Canopy openness does not seem to have a substantial effect on the density of filamentous algae and aquatic plants. Filamentous algae and aquatic plants were commonly not observed at sites with closed canopies, but they were also not observed at sites with open canopies. Other categories of plant-density data also were ambiguous; for example, there may be a weak relation between moderate densities of aquatic moss and less canopy openness.

Differences and variability in benthic (periphyton) chlorophyll $a$ concentrations and plant densities in streams generally do not correlate well with measured nutrient concentrations (Dodds and Welch, 2000). The comparisons examined here, however, do show a relation between median chlorophyll $a$ concentrations and canopy openness. The median values for all stations in the categories seem to be higher for opencanopy sites than for closed-canopy sites.

\section{Relations Among Categorical Data}

Comparison of nutrient and chlorophyll $a$ concentrations with the distribution of NPDES-permitted dischargers among Massachusetts nutrient ecoregions reveals that the distribution of major NPDES-permitted dischargers upstream from sampling stations appears to be related to the lake-based phosphorus nutrient ecoregions (fig. 1 and 14, at end of report); and other landscape factors, such as geology and soils, also may affect water quality, but are not examined in this report. In general, the highest concentrations of total phosphorus and total nitrogen are present at stations downstream from major NPDES-permitted dischargers that are in high-nutrient ecoregions. The lowest nutrient concentrations generally appear at stations with no upstream NPDES-permitted dischargers in low-nutrient ecoregions. Stations downstream from minor NPDES-permitted dischargers (red-colored symbols) usually are characterized by intermediate nutrient concentrations and are found in the intermediate- and high-nutrient ecoregions; no minor NPDES-permitted dischargers are in the low-nutrient ecoregion. Increases in chlorophyll $a$ concentrations do not appear to be associated with increases in nutrient concentrations, regardless of nutrient ecoregion or the presence of upstream NPDES-permitted dischargers. The inclusion of open- and closed-canopy data with the nutrient ecoregions or dischargers similarly does not reveal any relations with median chlorophyll $a$ concentrations (fig. 15, at end of report).

Using the New England SPARROW model, Moore and others (2004) found that relatively high nutrient concentrations may be associated with permitted wastewater dischargers, agricultural land area, and urbanized land area. They also found that streamflows less than $2.83 \mathrm{~m}^{3} / \mathrm{s}$ and the existence of small (surface area less than $10 \mathrm{~km}^{2}$ ) impoundments were associated with losses in phosphorus. Although the present study did not explicitly examine land-use relations, urban areas with relatively high incidences of treatment plants have data similar to data from the intermediate- and high-nutrient ecoregions in Massachusetts.

\section{Correlations Among Water-Quality Variables}

Correlation analysis serves to determine how two parameters covary. The results of such analyses can be presented in the form of correlation matrices that show the relations among any number of parameters (tables 6 and 7). By matching the values in the matrices (correlation coefficients) to their associated parameters heading the rows and columns, it is possible to determine the fraction of the variation in one parameter that is correlated with the other. A negative value indicates an inverse relation. When considering all the data, very few of the parameters seem to be correlated. The strongest correlations, in general, are among the nutrients and specific conductance (table 6): total nitrogen and total phosphorus (0.610); total nitrogen and specific conductance (0.704); total phosphorus and specific conductance $(0.485)$. Simply stated, high concentrations of one nutrient can be expected in the presence of another. Because high nutrient concentrations may be associated with urban settings, high concentrations of other dissolved materials, such as salts, also may be expected, and these concentrations tend to increase specific-conductance measurements. Chlorophyll $a$ concentrations are only weakly correlated with concentrations of any of the nutrients. When the data are categorized on the basis of open or closed canopy, the correlation between total nitrogen and chlorophyll $a$ becomes stronger at open-canopy sites (0.381) than at closed-canopy sites (0.023); on the other hand, the correlation between percentage of open canopy and chlorophyll $a$ at open-canopy sites (0.003) is not as strong as it is at closed-canopy sites (0.259) (table 8).

Stronger correlations can be made by dividing the data on the basis of Massachusetts nutrient ecoregion (table 7). In these views of the data, relatively strong correlations (correlation coefficients greater than 0.500) can be seen among total phosphorus, total dissolved nitrogen, and chlorophyll $a$ in the low-nutrient ecoregion. The correlation becomes weaker for total phosphorus in the intermediate-nutrient ecoregion, and is generally weakest in the high-nutrient ecoregion. The correlations among nutrients and specific conductance are weakest in the low-nutrient ecoregion and strongest in the intermediate-nutrient ecoregion. In the low-nutrient ecoregion, there are also strong negative correlations: (1) of total nitrogen and total phosphorus with dissolved oxygen; (2) of specific conductance with color; (3) of DO or percentage of openness with both total nitrogen and total phosphorus concentrations; and (4) of drainage basin area with both total phosphorus and total nitrogen. These correlations are not as strongly negative, or are slightly positive, in the intermediate- or highnutrient ecoregions. 
Table 6. Correlation coefficients among major water-quality parameters and percentage of open canopy and drainage area.

[Only values above the diagonal values of 1.000 are presented. The values below the diagonal mirror values above the diagonal and have been replaced by "-" to simplify the table. Coefficients (except for diagonal values=1.000) that represent relatively high correlations greater than 0.500 or less than -0.500 are shaded. Negative correlation coefficients indicate inverse relations]

\begin{tabular}{lcccccccccc}
\hline & $\begin{array}{c}\text { Percent- } \\
\text { age of } \\
\text { open } \\
\text { canopy }\end{array}$ & $\begin{array}{c}\text { Drain- } \\
\text { age } \\
\text { area }\end{array}$ & $\begin{array}{c}\text { Total } \\
\text { dissolved } \\
\text { nitrogen }\end{array}$ & $\begin{array}{c}\text { Total } \\
\text { nitrogen }\end{array}$ & $\begin{array}{c}\text { Total } \\
\text { phos- } \\
\text { phorus }\end{array}$ & $\begin{array}{c}\text { Chloro- } \\
\text { phyll a }\end{array}$ & Color & Turbidity & $\begin{array}{c}\text { Specific } \\
\text { conduc- } \\
\text { tance }\end{array}$ & $\begin{array}{c}\text { Dis- } \\
\text { solved } \\
\text { oxygen }\end{array}$ \\
\hline Percentage of open canopy & 1.000 & 0.543 & 0.021 & 0.037 & 0.026 & 0.496 & -0.014 & -0.047 & 0.088 & 0.188 \\
Drainage area & - & 1.000 & .013 & .037 & .130 & .195 & -.024 & .014 & .101 & .202 \\
Total dissolved nitrogen & - & - & 1.000 & .993 & .590 & .446 & -.148 & -.003 & .697 & -.189 \\
Total nitrogen & - & - & - & 1.000 & .610 & .460 & -.124 & .050 & .704 & -.225 \\
Total phosphorus & - & - & - & - & 1.000 & .326 & -.073 & .029 & .485 & -.205 \\
Chlorophyll $a$ & - & - & - & - & - & 1.000 & -.168 & -.075 & .317 & -.145 \\
Color & - & - & - & - & - & - & 1.000 & .608 & -.166 & -.427 \\
Turbidity & - & - & - & - & - & - & - & 1.000 & .097 & -.505 \\
Specific conductance & - & - & - & - & - & - & - & - & 1.000 & -.211 \\
Dissolved oxygen & - & - & - & - & - & - & - & - & - & 1.000 \\
\hline
\end{tabular}

\section{Relations Among Chlorophyll a, Nitrogen, Phosphorus, and Canopy Openness}

Individual relations between chlorophyll $a$ and the principal parameters (total nitrogen, total phosphorus, their ratios, and canopy openness) that might be expected to affect its concentration were examined graphically and by performing linear regression analysis. Increasing median chlorophyll $a$ concentrations only seem weakly related to increasing canopy openness, regardless of nutrient concentration or the ratio of total nitrogen to total phosphorus (fig. 16, at end of report). The regression coefficients among these variables are quite low (table 8).

Although separating the stations on the basis of open or closed canopies generally increases the regression coefficients somewhat, these regression coefficients remain low, indicating weak relations between chlorophyll $a$ and the various independent variables (table 8). In the closed-canopy category, the correlation coefficient of 0.259 indicates that the median total nitrogen concentration explains about 26 percent of the variation in median chlorophyll $a$. Among open-canopy sites, total nitrogen explains about 38 percent of the variation. The other regressions explain generally less than 5 percent of the variation.

\section{Stream-Velocity Effects}

Stream velocity was considered as a factor possibly affecting periphyton chlorophyll $a$ concentrations. Because stream velocity was estimated visually, and not measured directly, continuously varying data were unavailable.

Surrogate data, such as antecedent high discharges and stream slope, were used instead to estimate stream velocity.

\section{Effect of Antecedent Flows}

One factor that can affect periphyton density and hence the chlorophyll $a$ concentration is the occurrence of antecedent stormflows that can scour the periphyton from rocks. To study the effect of antecedent flow conditions on chlorophyll $a$, the MassDEP DWM selected the 28-day time period preceding periphyton sampling (Steven Halterman, Massachusetts Department of Environmental Protection, Division of Watershed Management, written commun., 2006). If streamflow exceeded 300 percent of the annual median discharge, the chlorophyll $a$ data were examined to determine whether a scouring effect could be observed (Biggs, 2000); that is, if chlorophyll $a$ concentrations routinely declined after such a storm between sampling dates, then the decline 
Table 7. Correlation coefficients among water-quality parameters, percentage of open canopy, and drainage area based on Massachusetts nutrient ecoregions.

[Only values above the diagonal values of 1.000 are presented. The values below the diagonal mirror values above the diagonal and have been replaced by "-" to simplify the table. Coefficients (except for diagonal values=1.000) that represent relatively high correlations greater than 0.500 or less than -0.500 are shaded. Negative correlation coefficients indicate inverse relations]

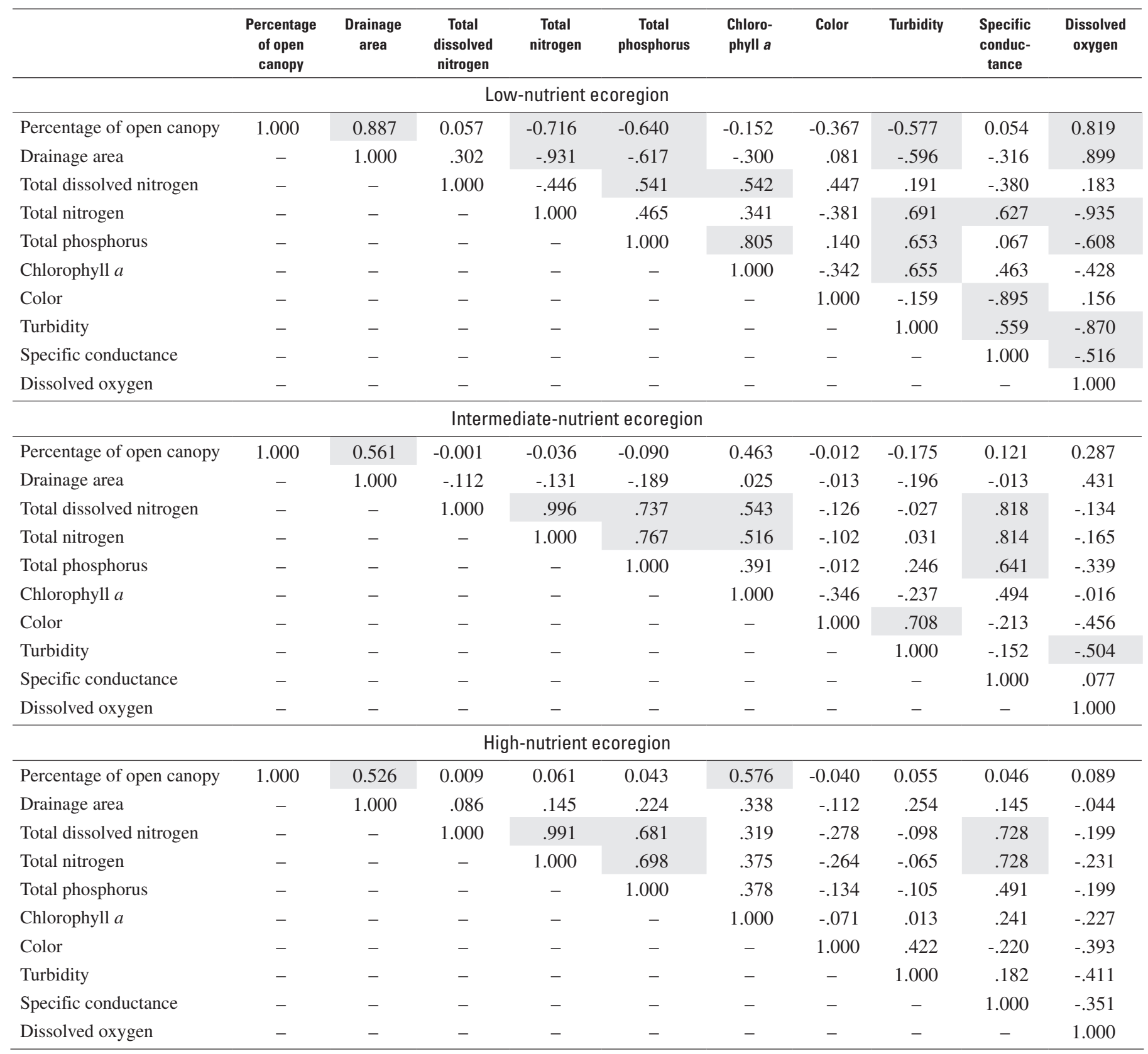


Table 8. Regression coefficients for chlorophyll $a$ versus total phosphorus, total nitrogen, the ratio of total nitrogen to total phosphorus, and percentage of open canopy for all sites, closed-canopy sites, and open-canopy sites.

[TP, total phosphorus; $\mathrm{TN}$, total nitrogen; $\mathrm{R}^{2}$, regression coefficient]

\begin{tabular}{lc}
\multicolumn{1}{c}{ All sites } & $\mathbf{R}^{2}$ \\
\hline Chlorophyll $a$ versus TP & 0.040 \\
Chlorophyll $a$ versus TN & .077 \\
Chlorophyll $a$ versus TN:TP & .001 \\
Chlorophyll $a$ versus percentage of open canopy & .090 \\
\hline \multicolumn{1}{c}{ Closed-canopy sites } & 0.039 \\
\hline Chlorophyll $a$ versus TP & .023 \\
Chlorophyll $a$ versus TN & .001 \\
Chlorophyll $a$ versus TN:TP & .259 \\
Chlorophyll $a$ versus percentage of open canopy & \\
\hline \multicolumn{1}{c}{ Open-canopy sites } & 0.154 \\
\hline Chlorophyll $a$ versus TP & .381 \\
Chlorophyll $a$ versus TN & .013 \\
Chlorophyll $a$ versus TN:TP & .003 \\
Chlorophyll $a$ versus percentage of open canopy & \\
\hline
\end{tabular}

could be ascribed to the scouring effect. Twelve stations had sufficient data for inclusion, and some had open- and closed-canopy sites. Data from 2001 and 2004 were included. Where no USGS continuous-monitoring station existed, the change in streamflow was estimated by selecting the nearest gaged stream of comparable drainage area as a surrogate. When applying these criteria to the data, no relation between antecedent storms and chlorophyll $a$ concentration changes was found; approximately equal numbers of increases (13) and decreases (14) were detected in chlorophyll $a$ concentrations in the 28 days following antecedent storms. Samples collected when there were no qualifying antecedent storms between sampling dates also had approximately equal numbers of increases (25) and decreases (24).

\section{Effect of Slope}

Although stream discharge and velocity were not measured as part of the field studies, in retrospect, the effect of velocity on the concentration of chlorophyll $a$ was determined by using channel slope. In lieu of velocity measurements, average upstream channel slope was used as a surrogate for velocity because streams with relatively high average slopes are assumed to have relatively high velocities at sampling sites. This assumption implies that increasing average velocities would be associated with increasing scour and diminishing chlorophyll $a$ concentrations. Average slopes for each catchment associated with a sampling station were obtained by the DWM (Mark Mattson, Massachusetts Department of Environmental Protection, Division of Watershed Management, oral commun., 2006) from the New England SPARROW model (Moore and others, 2004). Because Moore and others (2004) suggest that steep slopes may increase loadings of nutrients to streams, the relations of nutrients to slope also are examined here. Comparing the median nutrient and chlorophyll $a$ concentrations with stream slopes appears to show that with the exception of some elevated median concentrations of total nitrogen in streams with slopes less than 10 percent, no obvious relations with slope exist (fig. 17, at end of report). 


\section{Summary and Conclusions}

The U.S. Geological Survey (USGS) assessed Massachusetts water quality for developing nutrient criteria or a science-based framework for interpreting narrative criteria for nutrients. The USGS collected the water-quality data using a deterministic sampling design developed by the Massachusetts Department of Environmental Protection, Division of Watershed Management. The numbers of sites and numbers of samples collected at some sites varied each year. To avoid biasing study results toward conditions at sites that were sampled relatively frequently, median values of waterquality parameters were used to represent each sampling site.

Data were classified into categories for analysis by year, USEPA ecoregion, Massachusetts nutrient ecoregion, drainage-basin size, presence and type of upstream dischargers, and canopy openness. While the relations among nutrients and periphyton chlorophyll $a$ were the focus of this study, other water-quality characteristics, such as dissolved oxygen, specific conductance, $\mathrm{pH}$, and plant density also were examined.

More than half the sampling locations were downstream from NPDES-permitted wastewater-treatment plants. The majority of these treatment plants are located in Ecoregion XIV and the Massachusetts high-nutrient ecoregion. Major NPDES-permitted wastewater-treatment plants also tend to be located in large river basins.

Yearly differences in water-quality conditions were not substantial. Median total nitrogen and median total phosphorus concentrations were higher in USEPA Ecoregion XIV than in USEPA Ecoregion VIII. For USEPA Ecoregions VIII and $\mathrm{XIV}$, the data analyzed here indicate that the $25^{\text {th }}$-percentile median nutrient concentrations of total phosphorus and total nitrogen are lower than those recommended by the USEPA. Median turbidity values are somewhat higher than the USEPA recommendations. On the basis of drainage-basin size, only median nitrogen (total and dissolved) concentrations differed significantly, and the concentrations differed only between the largest and smallest basin-size classes. The presence or absence of major or minor NPDES-permitted dischargers upstream from sampling stations had the most obvious effect on median total phosphorus and nitrogen concentrations. The stations with no upstream dischargers had the lowest nutrient concentrations, followed by stations with minor dischargers; stations with major dischargers upstream had the highest median total phosphorus and nitrogen concentrations.

Among the categories of USEPA ecoregion, drainagebasin size, Massachusetts (lake-based) nutrient ecoregion, and presence of upstream dischargers, the median chlorophyll $a$ concentrations were not found to differ. For the categories of USEPA ecoregion, Massachusetts nutrient ecoregion, and presence of upstream dischargers, at least one of the distributions of total phosphorus and total nitrogen median values was found to differ. Median total phosphorus values among the drainage-basin-size classes were not found to differ, but at least one of the median total nitrogen values did differ. Further statistical testing indicated that, among drainage-basin-size classes, median total dissolved nitrogen and total nitrogen values did not differ between the smallest and intermediate basins or between the intermediate and largest basins; however, the values for the smallest basins were different from values for the largest basins. Among the Massachusetts nutrient ecoregions, median total phosphorus values for the intermediate- and high-nutrient ecoregions did not differ, but were significantly greater than in the low-nutrient ecoregion. Median total dissolved nitrogen concentrations did not differ among the three nutrient ecoregions, but the distributions of median total nitrogen values differed among all nutrient ecoregions. In the categories defined by NPDESpermitted dischargers, median total phosphorus and median total nitrogen had significantly different distributions in all three nutrient ecoregions. Median total dissolved nitrogen distributions did not differ between the stations that had either minor or no upstream dischargers, but both of these categories differed from the major discharger category.

Differences were observed when open- and closed-canopy sites were compared either at the same sampling location or among categorical groups. Open-canopy sites tended to have higher median periphyton chlorophyll $a$ concentrations than co-located closed-canopy sites.

No strong correlations could be determined for median periphyton chlorophyll $a$ concentrations with other waterquality characteristics. Nutrients correlated relatively strongly with each other and with specific conductance. These correlations further support the relations of the data with the presence of wastewater-treatment plants and other urban land-use effects. The possible effects of antecedent flows and stream slope on the median periphyton-chlorophyll $a$ concentrations were examined. No relations were determined. 


\section{Acknowledgments}

Environmental analysts Joan L. Beskenis and Mark D. Mattson and environmental engineers Dennis R. Dunn, Steven G. Halterman, and Russell A. Isaac, Massachusetts Department of Environmental Protection, Division of Watershed Management, designed the field studies and provided guidance for making this interpretive study relevant to the requirements for their development of water-quality criteria. The authors thank U.S. Geological Survey staff Timothy R. Driskell, Domenic Murino, Jr., Britt O. Stock, and Jason R. Sorenson for their work in collecting the field data on which much of this report's analysis is based. Virginia L. McGuire, hydrologist, U.S. Geological Survey, has provided this and other projects with invaluable technical support in applications of the S-PLUS data-analysis software package. David L. Lorenz, hydrologist, U.S. Geological Survey, assisted with advice on statistical analyses.

\section{References Cited}

Arar, E.J., and Collins, G.B., 1997, In-vitro determination of chlorophyll $a$ and pheophytin $a$ in marine and freshwater algae by fluorescence: Cincinnati, Ohio, National Exposure Research Laboratory, Office of Research and Development, U.S. Environmental Protection Agency, Method EPA 445.0, variously paged.

Biggs, B.J.F., 2000, Eutrophication of streams and rivers-Dissolved nutrient-chlorophyll relationships for benthic algae: Journal of the North American Benthological Society, v. 19, no. 1, p. 17-31.

Dodds, W.K., and Welch, E.B., 2000, Establishing nutrient criteria in streams: Journal of the North American Benthological Society, v. 19, no. 1, p. 186-196.

Fitzpatrick, F.A., Waite, I.R., D'Arconte, P.J., Meador, M.R., Maupin, M.A., and Gurtz, M.E., 1998, Revised methods for characterizing stream habitat in the National WaterQuality Assessment Program: U.S. Geological Survey Water-Resources Investigations Report 98-4052, 67 p.
Hach Company, 1984, Color Test Kit, Model CO-1: Loveland, Colo., Hach Company, 3 p.

Moore, R.B., Johnston, C.M., Robinson, K.W., and Deacon, J.R., 2004, Estimation of total nitrogen and phosphorus in New England streams using spatially referenced regression models: U.S. Geological Survey Scientific Investigations Report 2004-5012, 42 p.

Moulton, S.R., Kennen, J.G., Goldstein, R.M., and Hambrook, J.A., 2002, Revised protocols for sampling algal, invertebrate, and fish communities as part of the National WaterQuality Assessment Program: U.S. Geological Survey Open-File Report 02-150, 75 p.

Omernik, J.M., 1987, Ecoregions of the conterminous United States: Annals of the Association of American Geographers, v. 77 , p. $118-125$.

Patton, C.J., and Truitt, E.P., 1992, Methods of analysis by the U.S. Geological Survey National Water Quality Laboratory-Determination of total phosphorus by a Kjeldahl digestion method and an automated colorimetric finish that includes dialysis: U.S. Geological Survey Open-File Report 92-146, 39 p.

Patton, C.J., and Truitt, E.P., 2000, Methods of analysis by the U.S. Geological Survey National Water Quality Laboratory-Determination of ammonium plus organic nitrogen by a Kjeldahl digestion method and an automated photometric finish that includes digest cleanup by gas diffusion: U.S. Geological Survey Open-File Report 00-170, 31 p.

Riskin, M.L., Deacon, J.R., Liebman, M.L., and Robinson, K.W., 2003, Nutrient and chlorophyll relations in selected streams of the New England Coastal Basins in Massachusetts and New Hampshire, June-September 2001: U.S. Geological Survey Water-Resources Investigations Report 03-4191, 16 p.

Robertson, D.M., Saad, D.A., and Wieben, A.M., 2001, An alternative regionalization scheme for defining nutrient criteria for rivers and streams: U.S. Geological Survey WaterResources Investigations Report 01-4073, 57 p. 
Rohm, C.M., Omernik, J.M., and Kiilsgaard, C.W., 1995, Regional patterns of total phosphorus in lakes of the northeastern United States: Lake and Reservoir Management, v. 1, no. 1, p. 1-14 (color map).

U.S. Environmental Protection Agency, 2000, Ambient water quality criteria recommendations, information supporting the development of State and Tribal nutrient criteria for rivers and streams in Nutrient Ecoregion XIV: U.S Environmental Agency, EPA 822-B-00-022, variously paged.

U.S. Environmental Protection Agency, 2001, Ambient water quality criteria recommendations, information supporting the development of State and Tribal nutrient criteria for rivers and streams in Nutrient Ecoregion VIII: U.S Environmental Agency, EPA 822-B-01-015, variously paged.

Webb, W.E., Radtke, D.B., and Iwatsubo, R.T., 1999, Surfacewater sampling - Collection methods at flowing-water and still-water sites, in Wilde, F.D., Radtke, D.B., Gibs, Jacob, and Iwatsubo, R.T., eds., National field manual for the collection of water-quality data: U.S. Geological Survey Techniques of Water-Resources Investigations, book 9, chap. A4, section 4.1.1A, variously paged.

Wilde, F.D. and Gibs, Jacob, 1998, Turbidity, in Wilde, F.D., Radtke, D.B., Gibs, Jacob, and Iwatsubo, R.T., eds., National field manual for the collection of waterquality data: U.S. Geological Survey Techniques of Water-Resources Investigations, book 9, chap. A6, variously paged. 

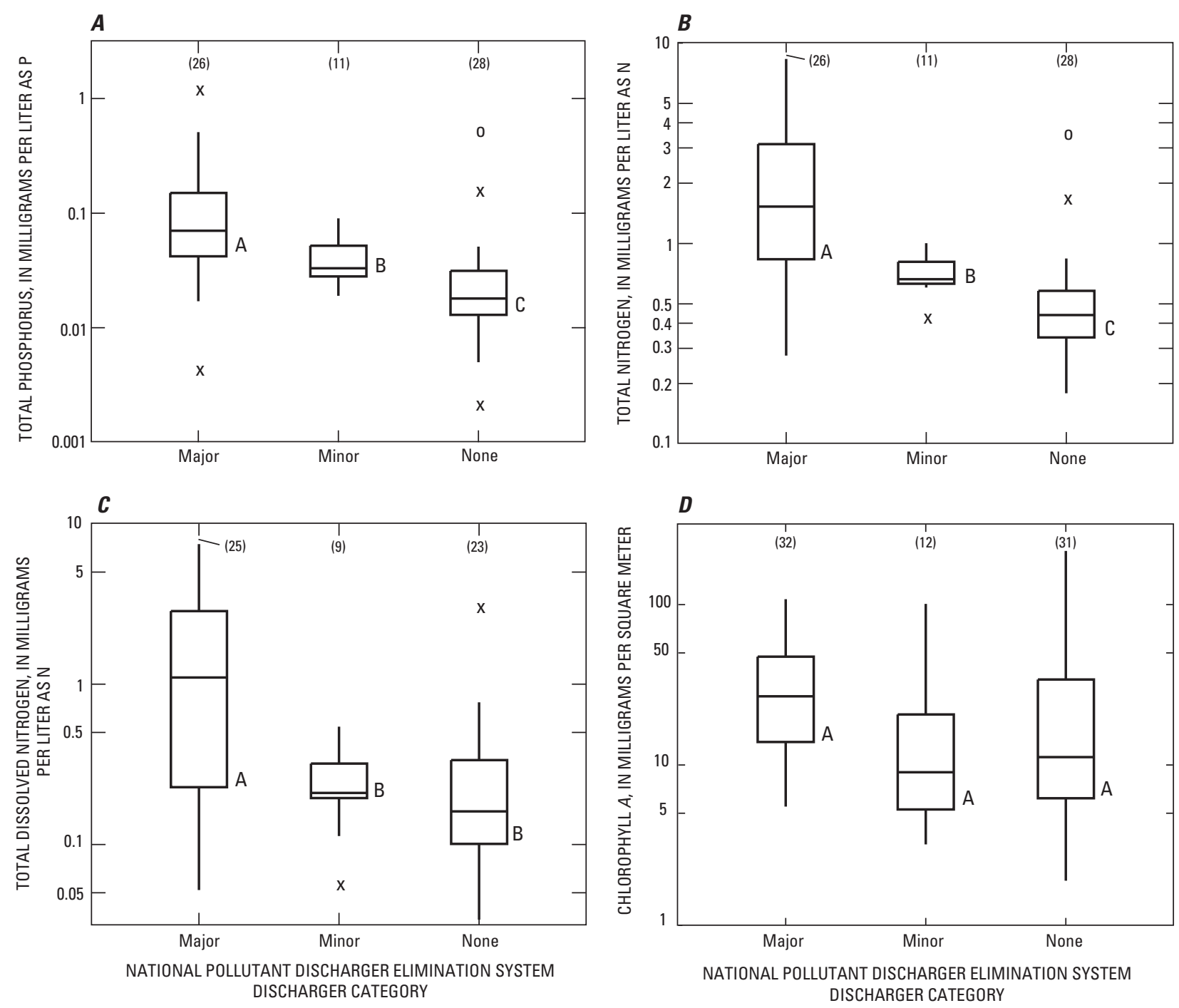

EXPLANATION

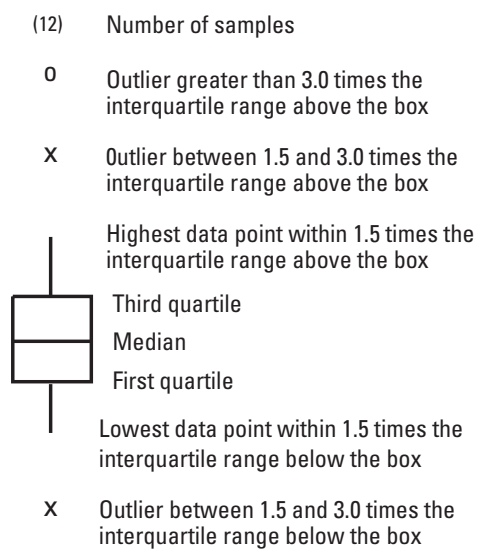

Figure 7. Distribution of median $(A)$ total phosphorus, $(B)$ total nitrogen, $(C)$ total dissolved nitrogen, and $(D)$ chlorophyll $a$ concentrations at all sampling sites by National Pollutant Discharge Elimination System discharger category in Massachusetts. The results of the Kruskal-Wallis rank sum test are represented as letters. Distributions of groups of data with at least one letter in common do not differ significantly. 

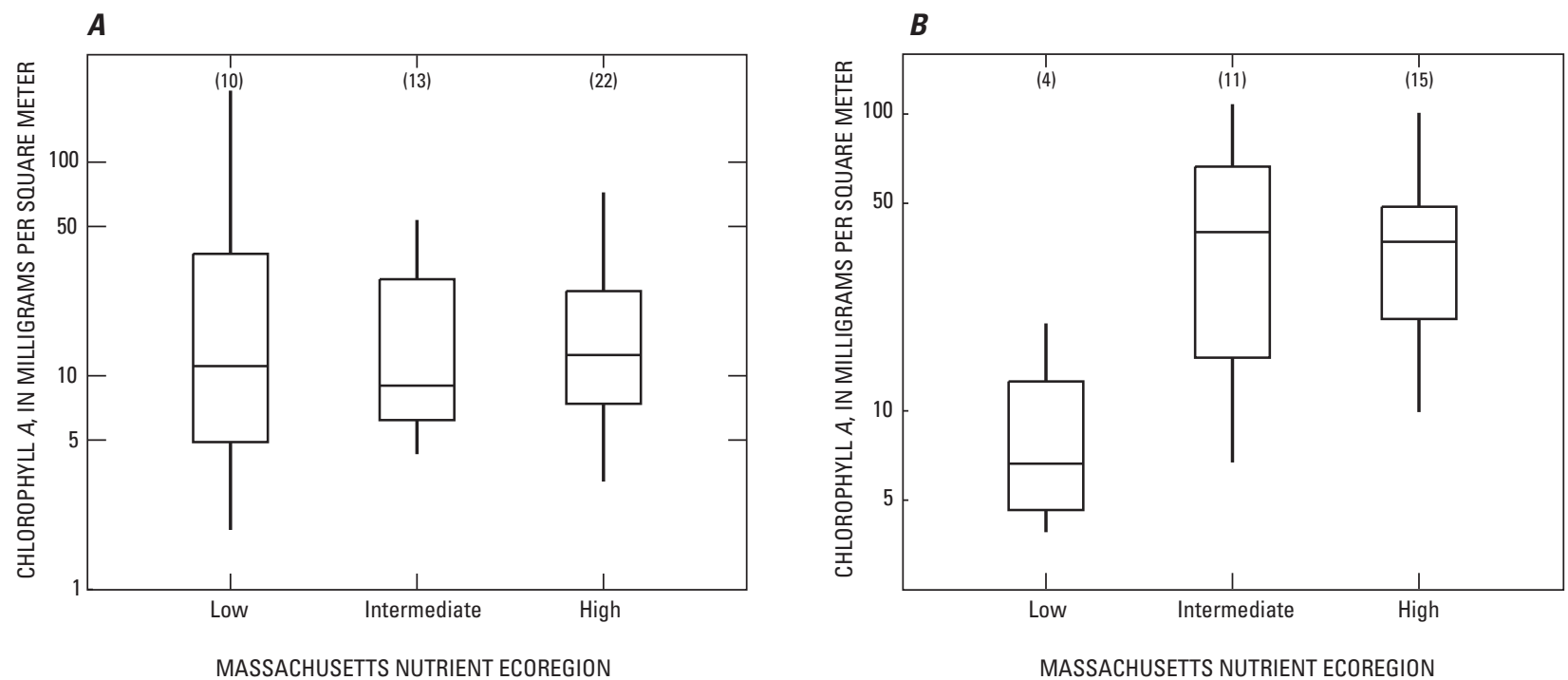

MASSACHUSETTS NUTRIENT ECOREGION

EXPLANATION

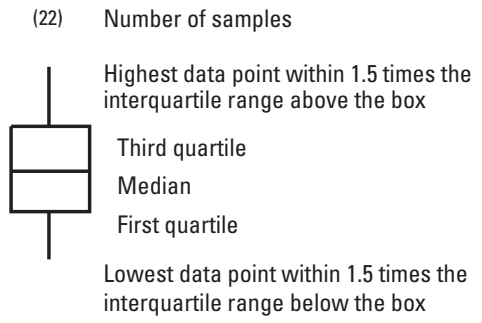

Figure 8. Distribution of median periphyton chlorophyll $a$ concentrations at $(A)$ closed-and $(B)$ open-canopy sampling sites by Massachusetts nutrient ecoregion. 

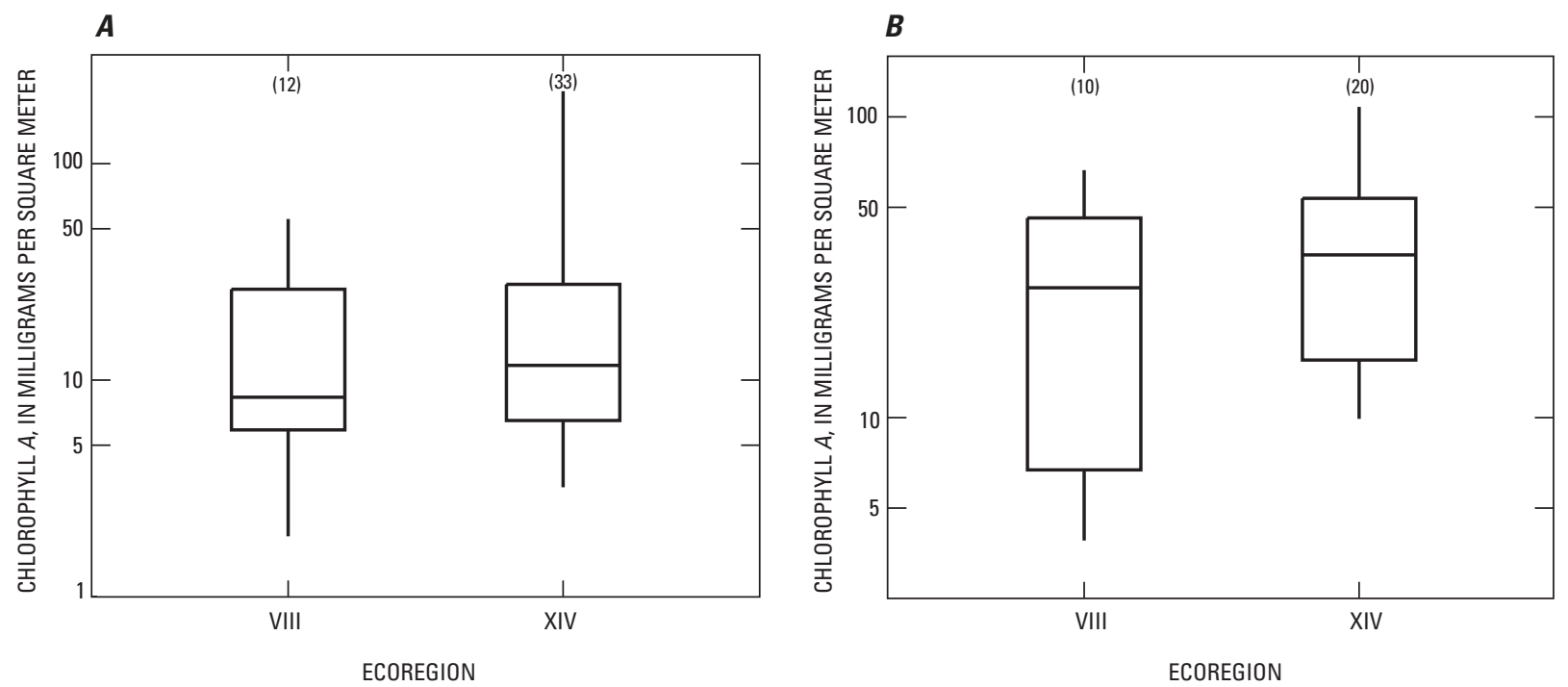

EXPLANATION

(10) Number of samples

Highest data point within 1.5 times the interquartile range above the box

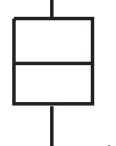

Third quartile

Median

First quartile

Lowest data point within 1.5 times the interquartile range below the box

Figure 9. Distribution of median periphyton chlorophyll $a$ concentrations at $(A)$ closed- and $(B)$ open-canopy sampling sites for U.S. Environmental Protection Agency ecoregions VIII and XIV in Massachusetts. 

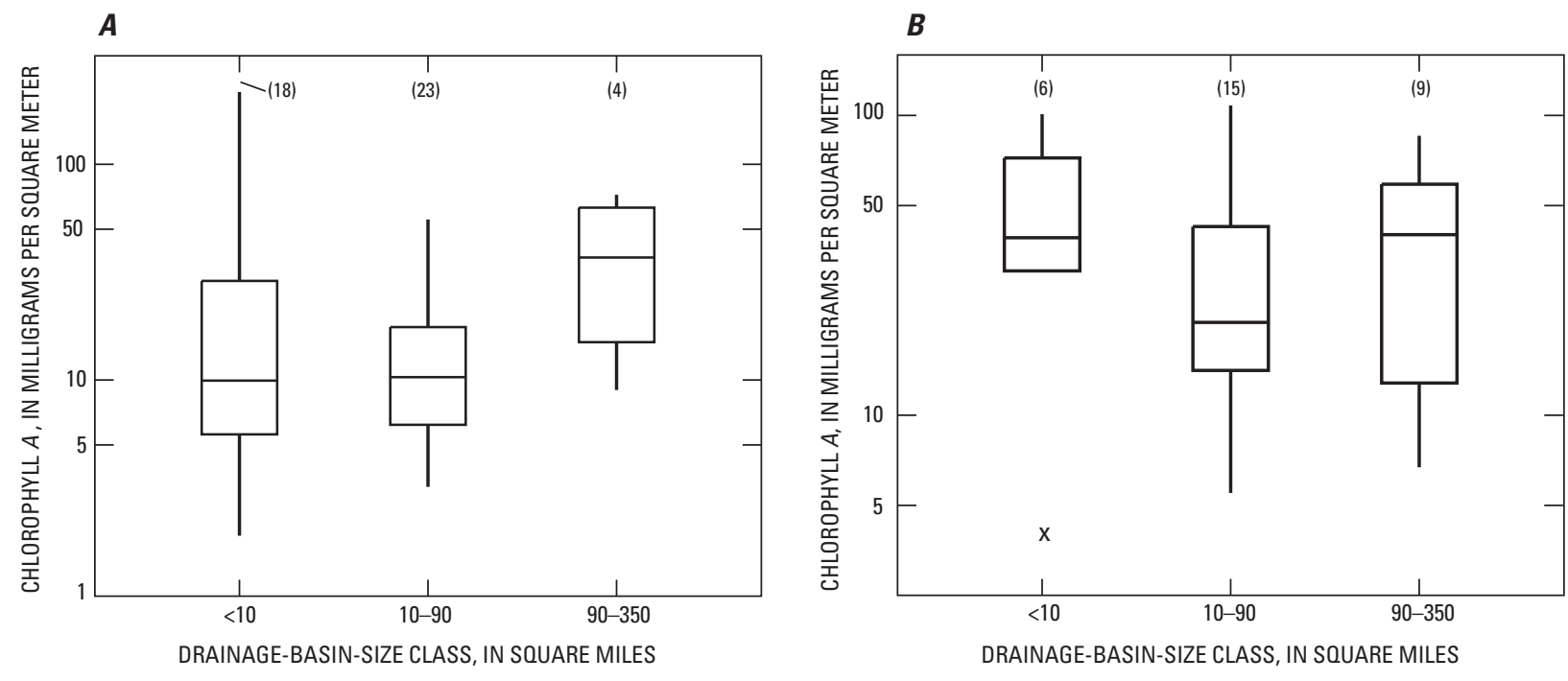

EXPLANATION

(23) Number of samples

Highest data point within 1.5 times the interquartile range above the box

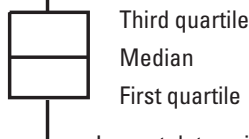

Lowest data point within 1.5 times the interquartile range below the box

$\mathrm{X} \quad$ Outlier between 1.5 and 3.0 times the interquartile range below the box

Figure 10. Distribution of median periphyton chlorophyll $a$ concentrations at $(A)$ closed- and $(B)$ open-canopy sampling sites by drainage-basin-size class in Massachusetts. 

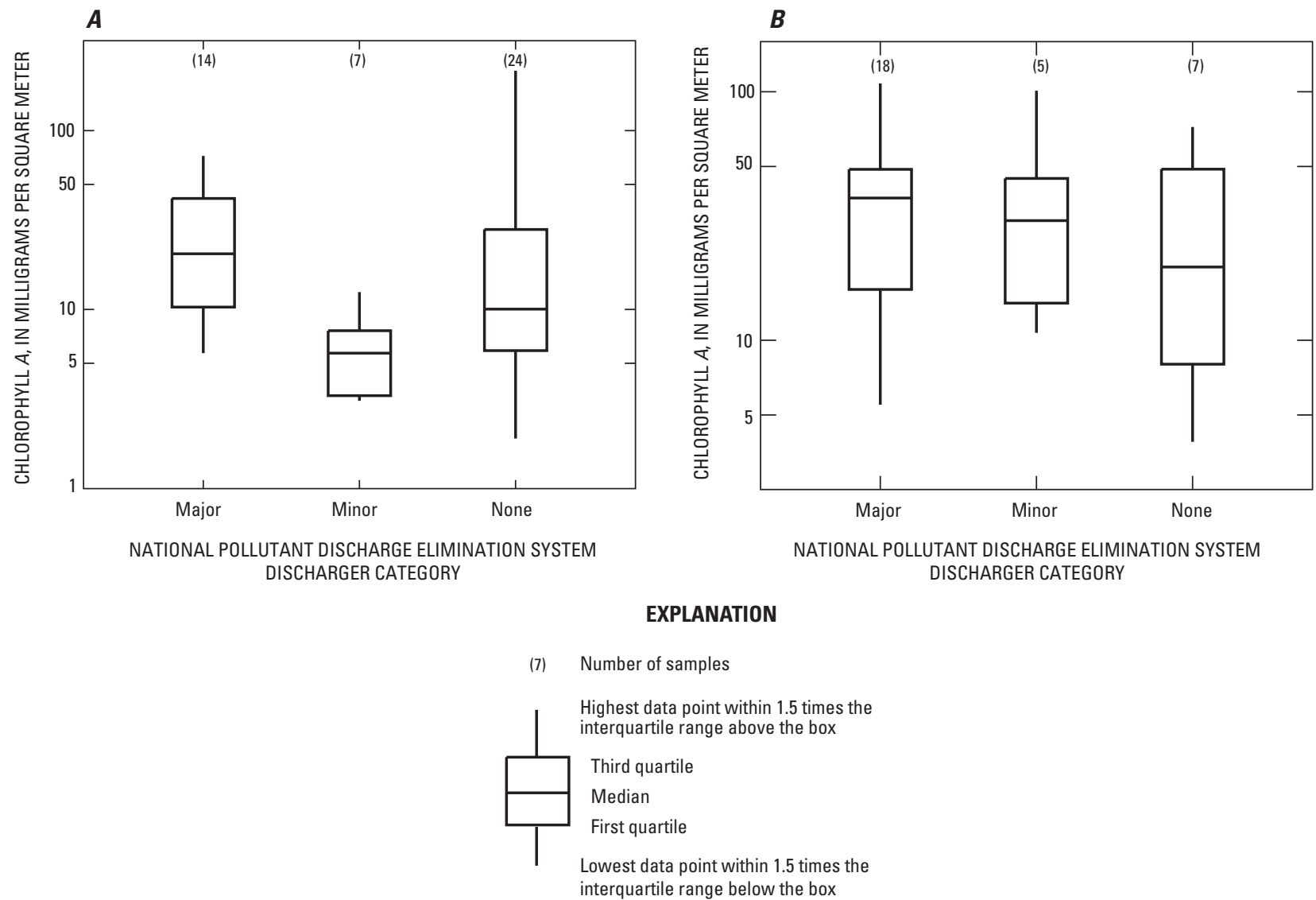

Figure 11. Distribution of median periphyton chlorophyll $a$ concentrations at $(A)$ closed-and $(B)$ open-canopy sampling sites by National Pollutant Discharge Elimination System discharger category in Massachusetts. 

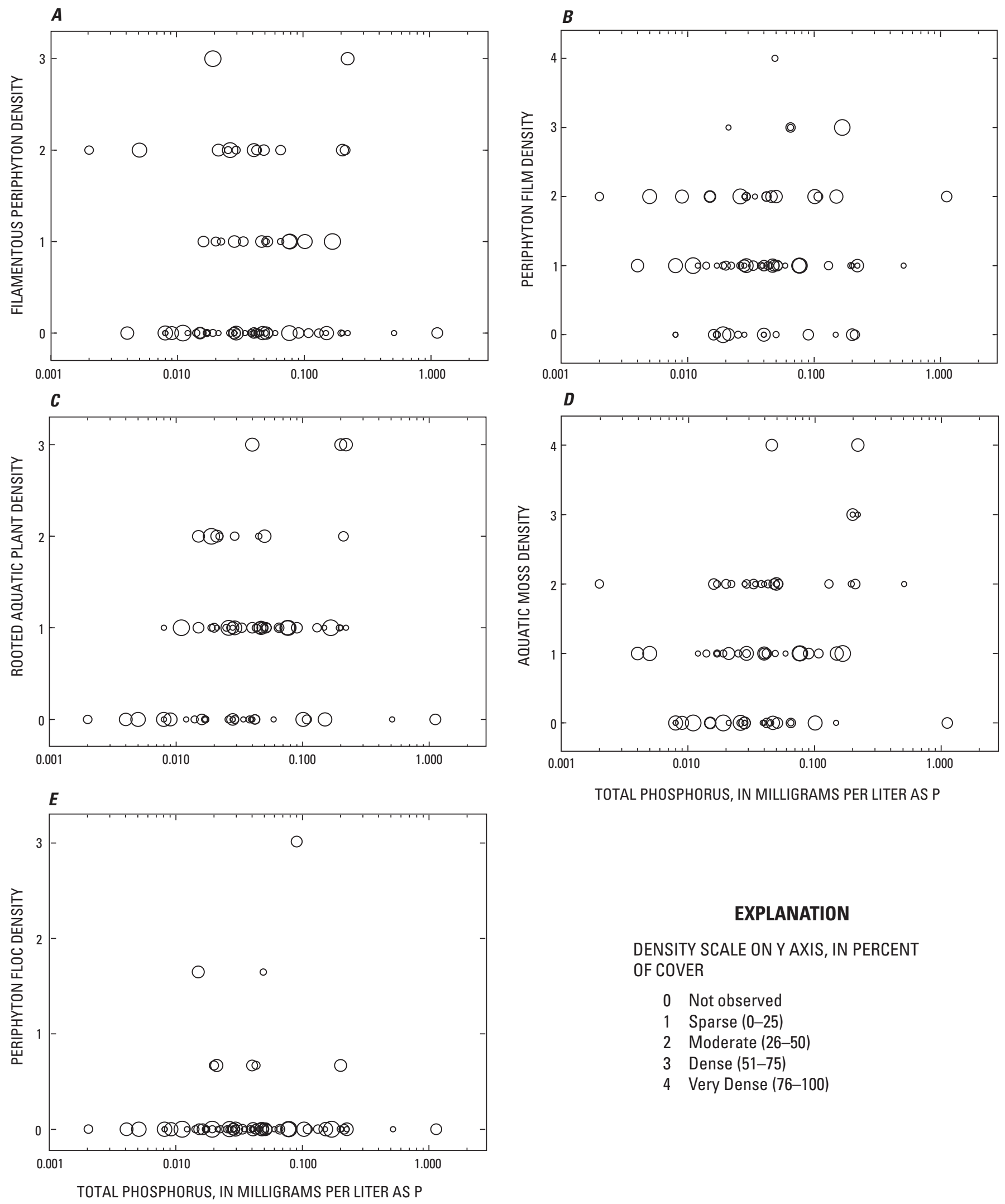

EXPLANATION

DENSITY SCALE ON Y AXIS, IN PERCENT OF COVER

0 Not observed

1 Sparse (0-25)

2 Moderate $(26-50)$

3 Dense (51-75)

4 Very Dense (76-100)

Figure 12. Density of $(A)$ filamentous periphyton, $(B)$ periphyton film, $(C)$ aquatic plants, $(D)$ aquatic moss, and $(E)$ periphyton floc as a function of median total phosphorus concentrations and the percentage of canopy openness at all sampling sites in Massachusetts. Circle size is proportional to canopy openness. 

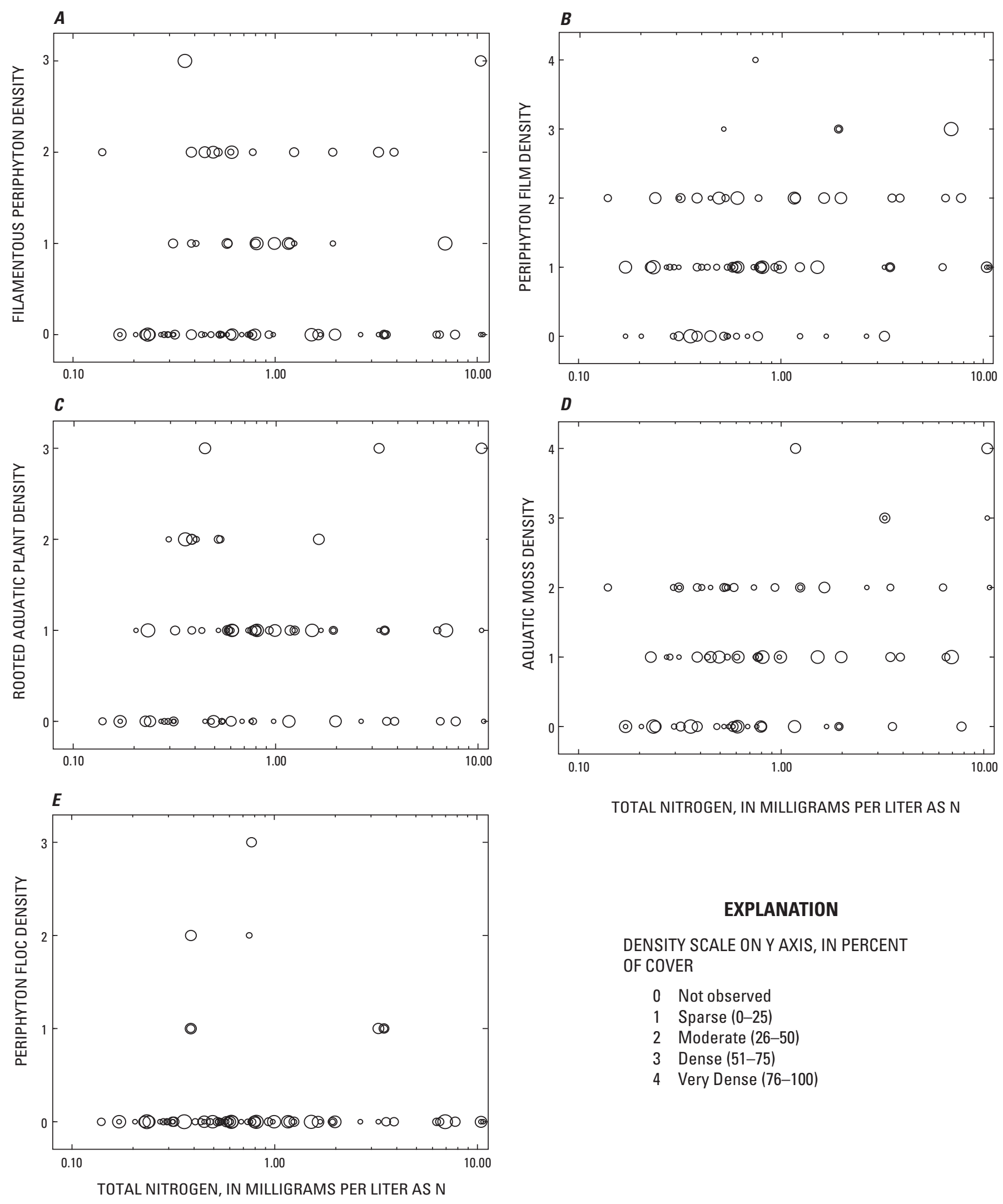

TOTAL NITROGEN, IN MILLIGRAMS PER LITER AS N

\section{EXPLANATION}

DENSITY SCALE ON Y AXIS, IN PERCENT OF COVER

0 Not observed

1 Sparse (0-25)

2 Moderate (26-50)

3 Dense (51-75)

4 Very Dense (76-100)

Figure 13. Density of $(A)$ filamentous periphyton, $(B)$ periphyton film, $(C)$ aquatic plants, $(D)$ aquatic moss, and $(E)$ periphyton floc as a function of median total nitrogen concentrations and the percentage of canopy openness at all sampling sites in Massachusetts. Circle size is proportional to canopy openness. 


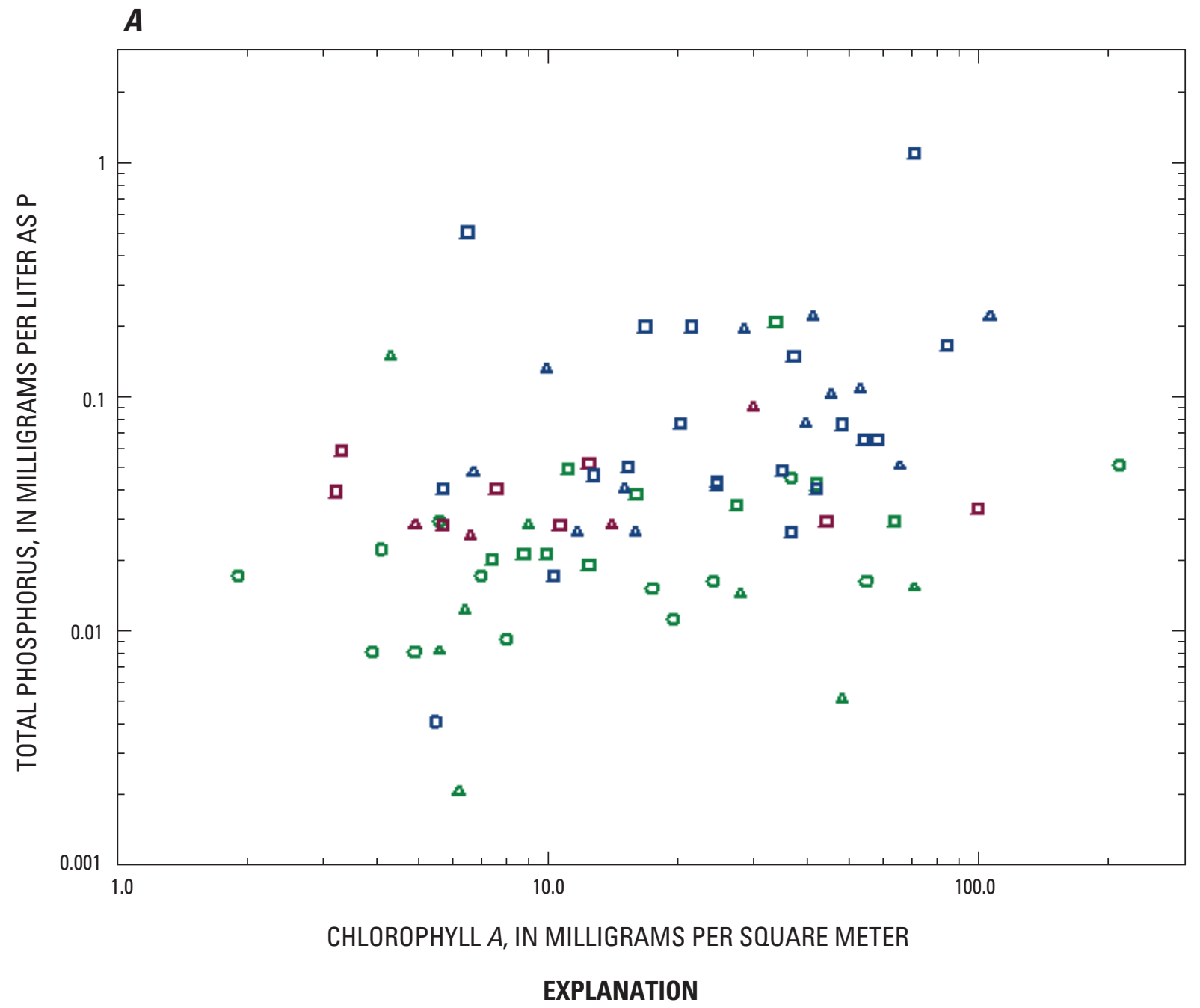

SYMBOL REPRESENTS MASSACHUSETTS NUTRIENT ECOREGION, AND COLOR

REPRESENTS TYPE OF NATIONAL POLLUTANT DISCHARGE ELIMINATION

SYSTEM DISCHARGER

$\begin{array}{lccc}\text { Low } & 0 & \circ & 0 \\ \text { Intermediate } & \Delta & \Delta & \Delta \\ \text { High } & \square & \square & \square \\ & \text { Major } & \text { Minor } & \text { None }\end{array}$

Figure 14. Median $(A)$ total phosphorus and $(B)$ total nitrogen concentrations as a function of median chlorophyll $a$ concentrations by Massachusetts nutrient ecoregion and National Pollutant Discharge Elimination System discharger category. 


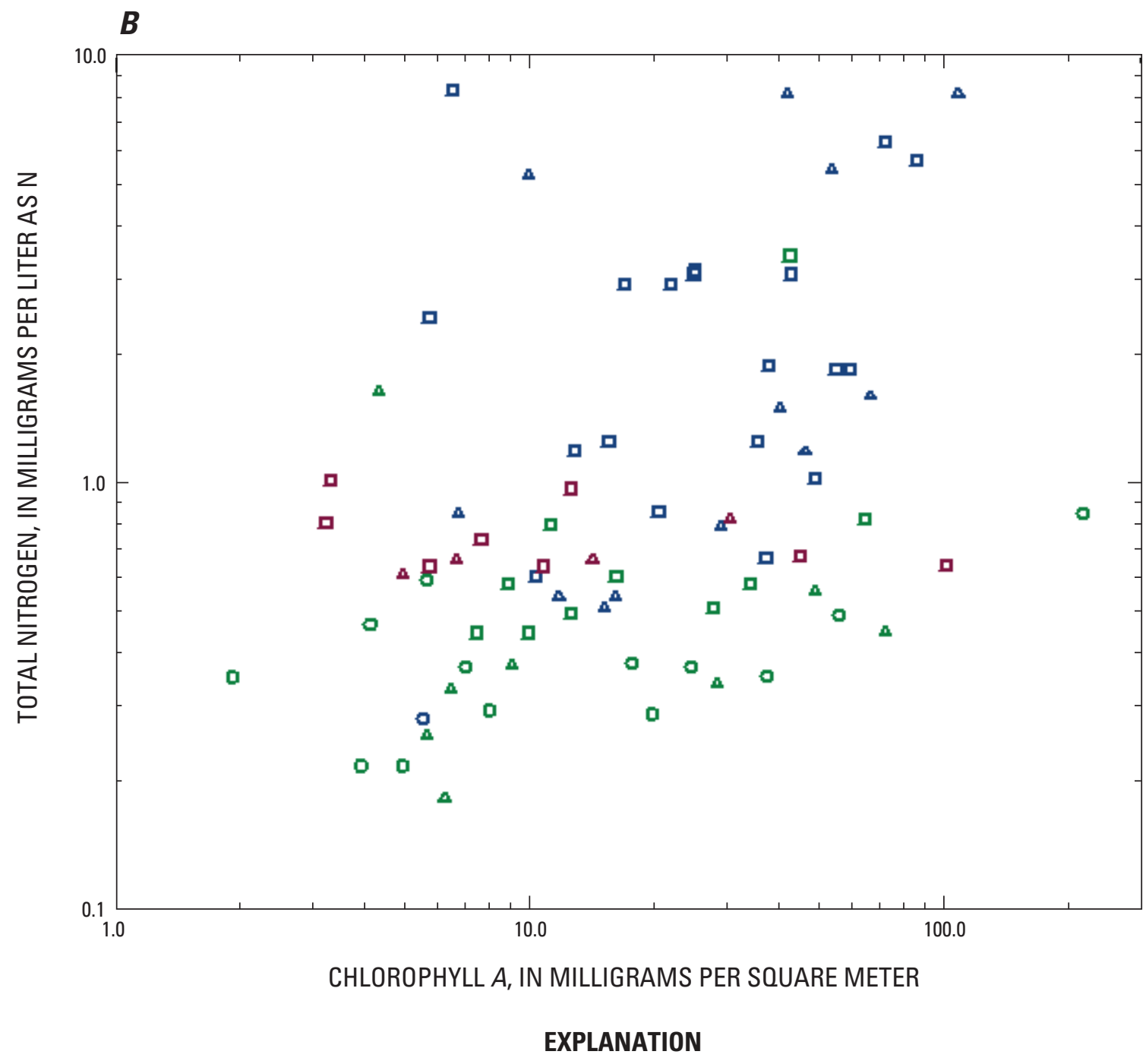

SYMBOL REPRESENTS MASSACHUSETTS NUTRIENT ECOREGION, AND COLOR
REPRESENTS TYPE OF NATIONAL POLLUTANT DISCHARGE ELIMINATION

SYSTEM DISCHARGER

$\begin{array}{lccc}\text { Low } & 0 & 0 & 0 \\ \text { Intermediate } & \Delta & \Delta & \Delta \\ \text { High } & \square & \square & \square \\ & \text { Major } & \text { Minor } & \text { None }\end{array}$

Figure 14. Median $(A)$ total phosphorus and $(B)$ total nitrogen concentrations as a function of median chlorophyll $a$ concentrations by Massachusetts nutrient ecoregion and National Pollutant Discharge Elimination System discharger category.-Continued 


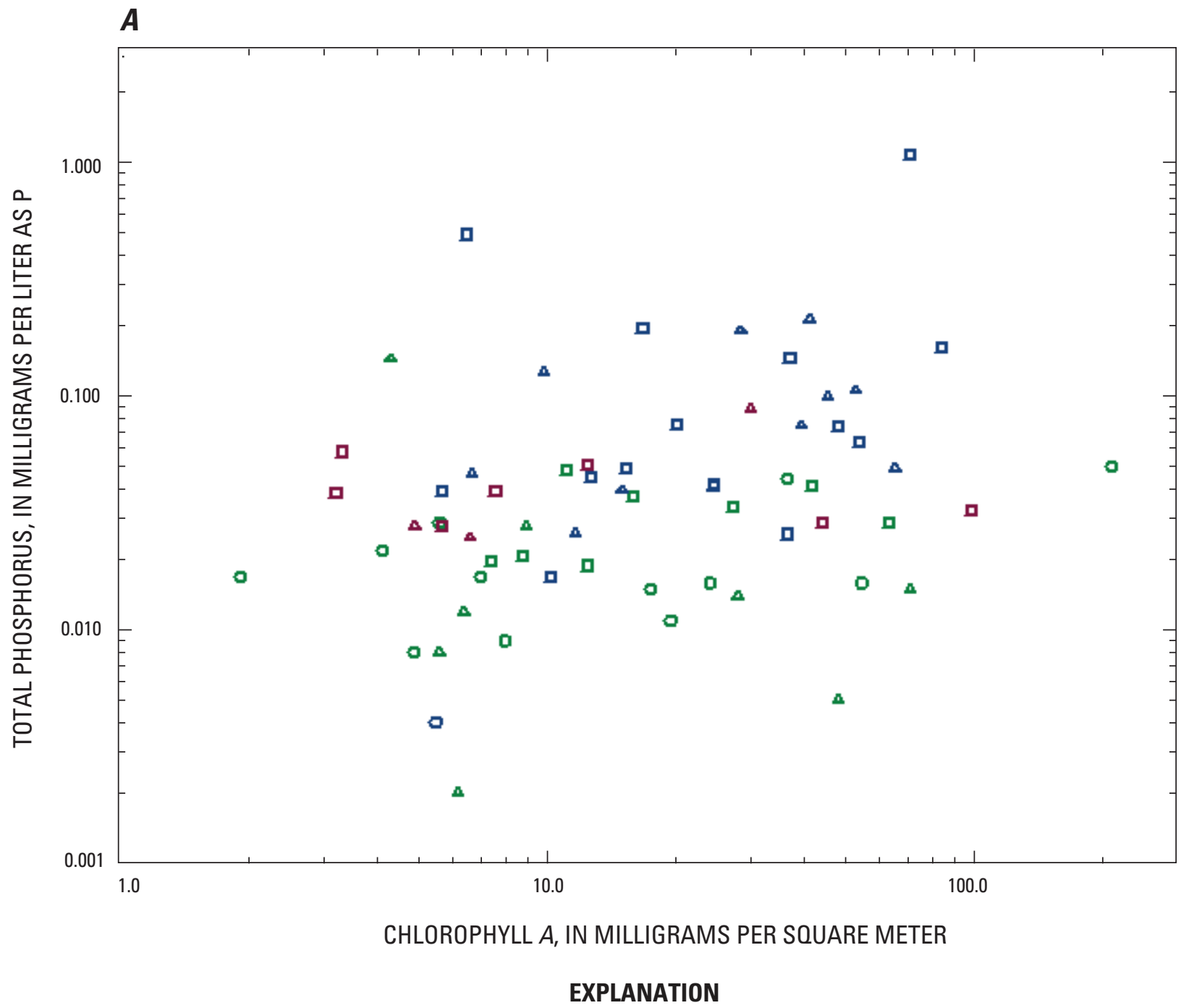

SYMBOL REPRESENTS MASSACHUSETTS NUTRIENT ECOREGION, AND COLOR REPRESENTS TYPE OF NATIONAL POLLUTANT DISCHARGE ELIMINATION SYSTEM DISCHARGER

$\begin{array}{lccc}\text { Low } & 0 & 0 & 0 \\ \text { Intermediate } & \Delta & \Delta & \Delta \\ \text { High } & \square & \square & \square \\ & \text { Major } & \text { Minor } & \text { None }\end{array}$

Figure 15. Median $(A, B)$ total phosphorus and $(C, D)$ total nitrogen concentrations as a function of median chlorophyll $a$ concentrations at $(A, C)$ closed- and $(B, D)$ open-canopy sites by Massachusetts nutrient ecoregion and National Pollutant Discharge Elimination System discharger category. 


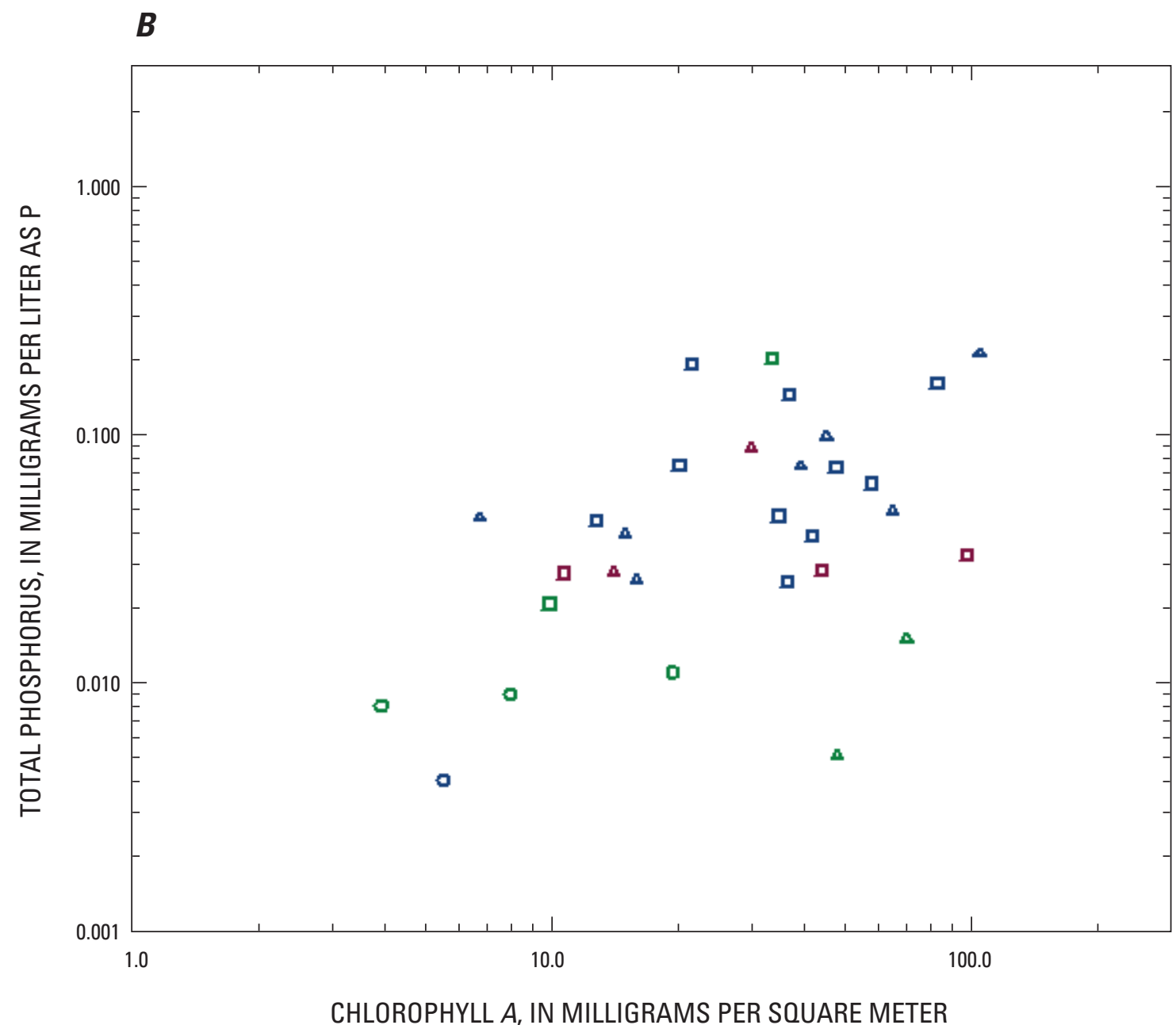

\section{EXPLANATION}

SYMBOL REPRESENTS MASSACHUSETTS NUTRIENT ECOREGION, AND COLOR REPRESENTS TYPE OF NATIONAL POLLUTANT DISCHARGE ELIMINATION SYSTEM DISCHARGER

$\begin{array}{lccc}\text { Low } & 0 & 0 & 0 \\ \text { Intermediate } & \Delta & \Delta & \Delta \\ \text { High } & \square & \square & \square \\ & \text { Major } & \text { Minor } & \text { None }\end{array}$

Figure 15. Median $(A, B)$ total phosphorus and $(C, D)$ total nitrogen concentrations as a function of median chlorophyll $a$ concentrations at $(A, C)$ closed- and $(B, D)$ open-canopy sites by Massachusetts nutrient ecoregion and National Pollutant Discharge Elimination System discharger category. - Continued 


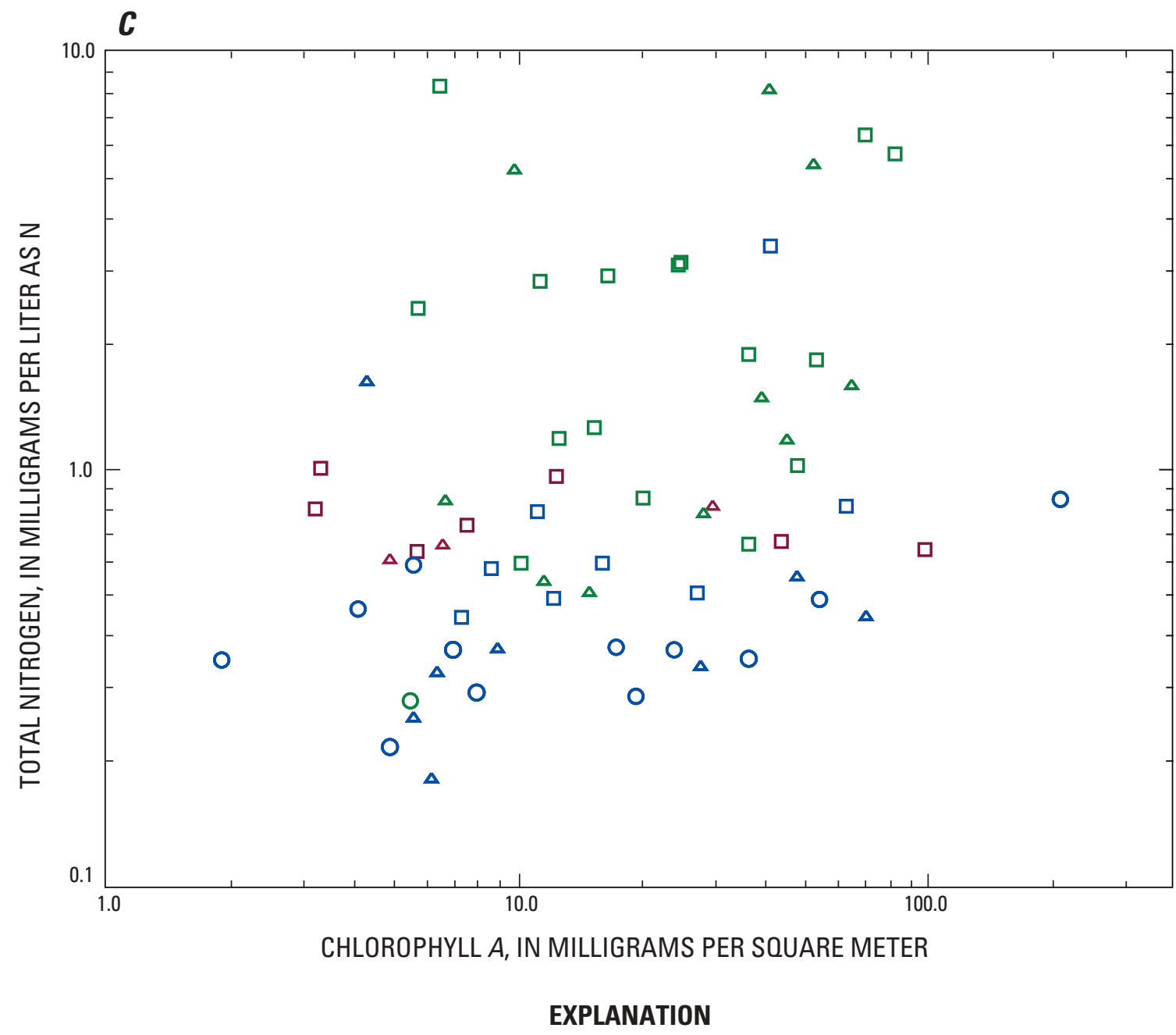

SYMBOL REPRESENTS MASSACHUSETTS NUTRIENT ECOREGION, AND COLOR REPRESENTS TYPE OF NATIONAL POLLUTANT DISCHARGE ELIMINATION SYSTEM DISCHARGER

$\begin{array}{lccc}\text { Low } & 0 & 0 & 0 \\ \text { Intermediate } & \Delta & \Delta & \Delta \\ \text { High } & \square & \square & \square \\ & \text { Major } & \text { Minor } & \text { None }\end{array}$

Figure 15. Median $(A, B)$ total phosphorus and $(C, D)$ total nitrogen concentrations as a function of median chlorophyll $a$ concentrations at $(A, C)$ closed-and $(B, D)$ open-canopy sites by Massachusetts nutrient ecoregion and National Pollutant Discharge Elimination System discharger category. - Continued 


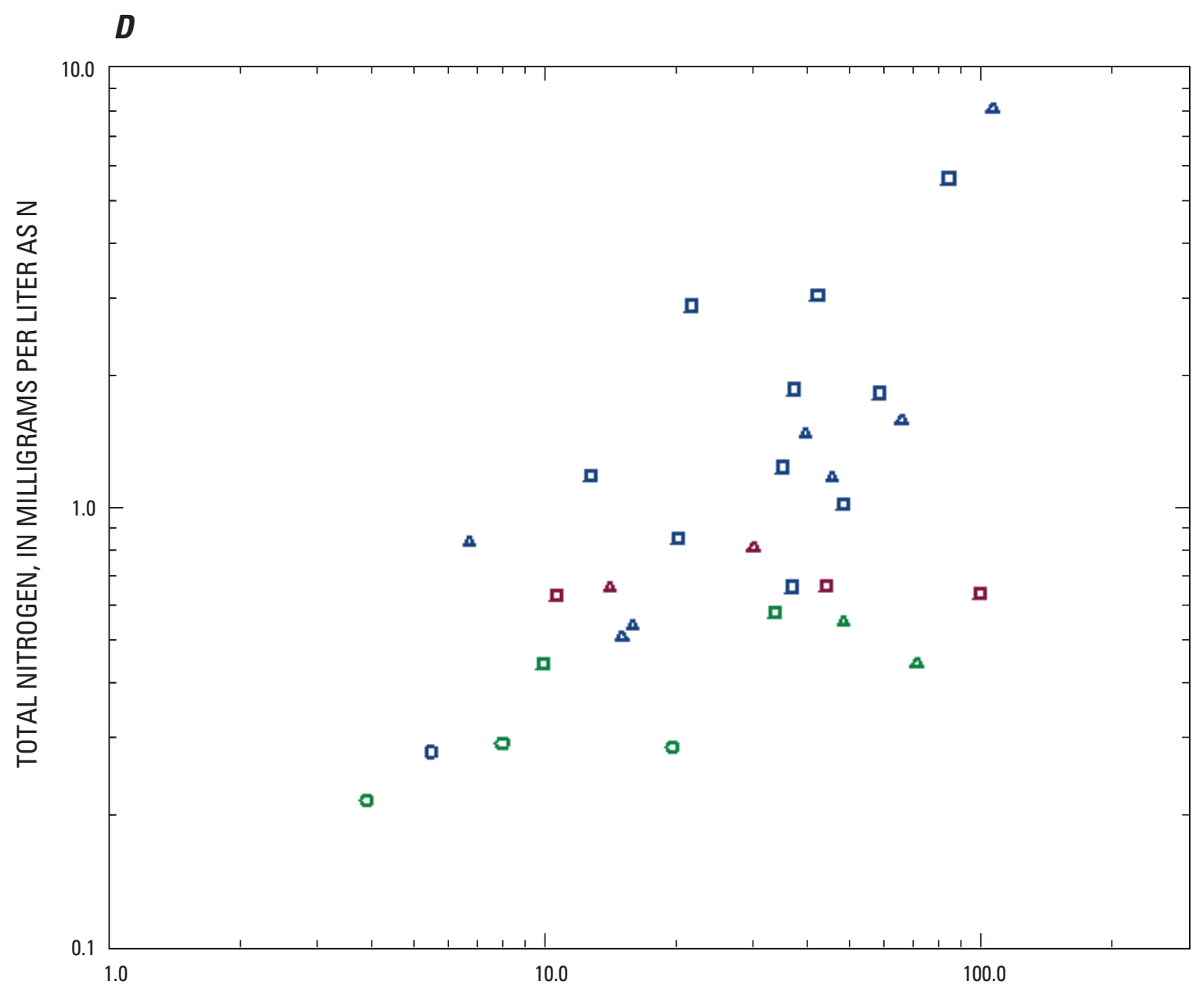

CHLOROPHYLL $A$, IN MILLIGRAMS PER SQUARE METER

\section{EXPLANATION}

SYMBOL REPRESENTS MASSACHUSETTS NUTRIENT ECOREGION, AND COLOR REPRESENTS TYPE OF NATIONAL POLLUTANT DISCHARGE ELIMINATION SYSTEM DISCHARGER

$\begin{array}{lccc}\text { Low } & 0 & 0 & 0 \\ \text { Intermediate } & \Delta & \Delta & \Delta \\ \text { High } & \square & \square & \square \\ & \text { Major } & \text { Minor } & \text { None }\end{array}$

Figure 15. Median $(A, B)$ total phosphorus and $(C, D)$ total nitrogen concentrations as a function of median chlorophyll $a$ concentrations at $(A, C)$ closed- and $(B, D)$ open-canopy sites by Massachusetts nutrient ecoregion and National Pollutant Discharge Elimination System discharger category. - Continued 

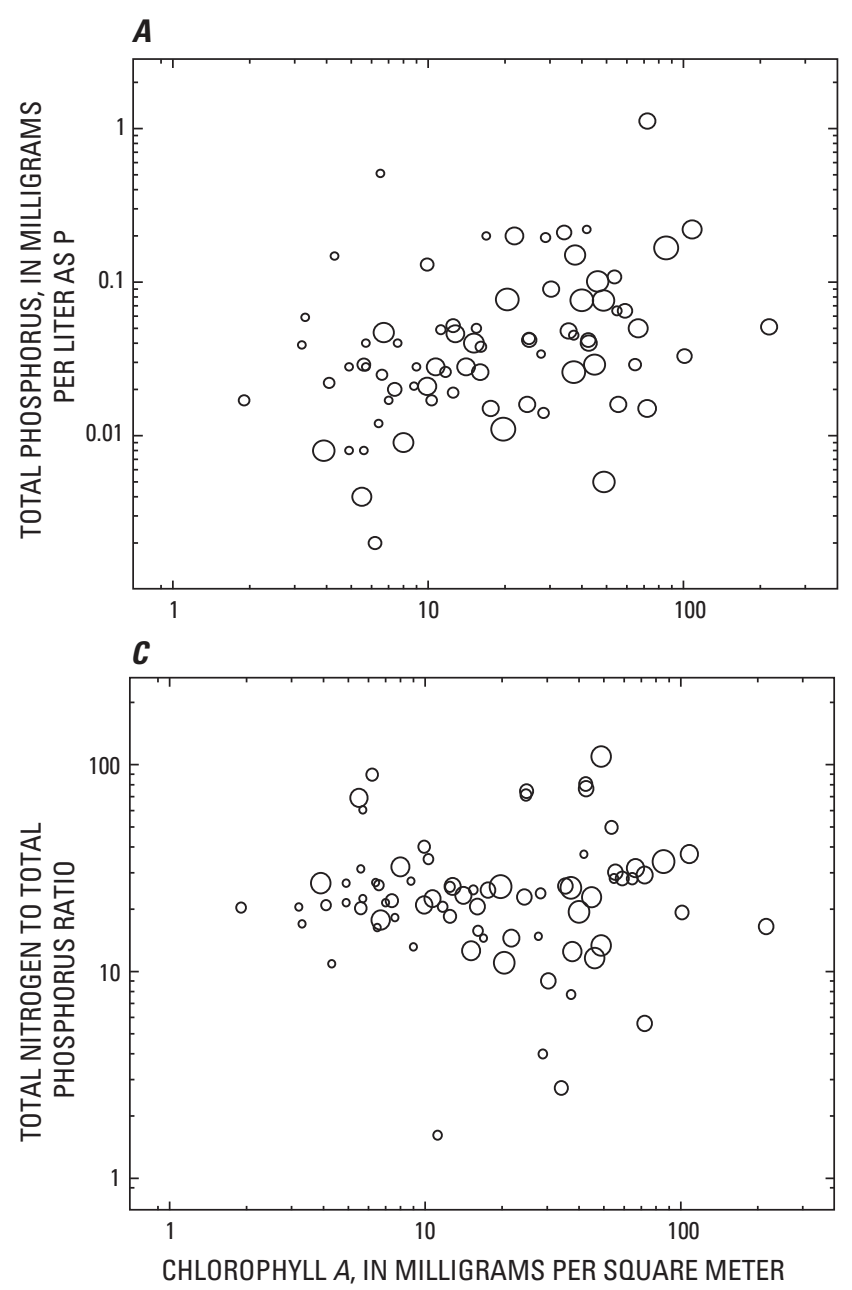

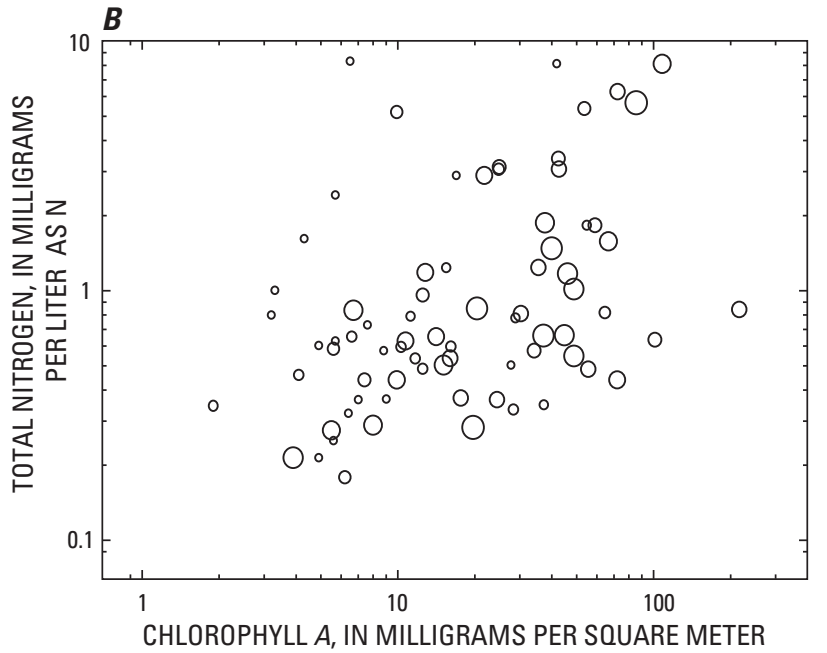

Figure 16. Median $(A)$ total phosphorus concentrations, $(B)$ total nitrogen concentrations, and $(C)$ ratio of total nitrogen to total phosphorus as a function of median chlorophyll $a$ concentrations and percentage of canopy openness in Massachusetts. Circle size is proportional to canopy openness. 

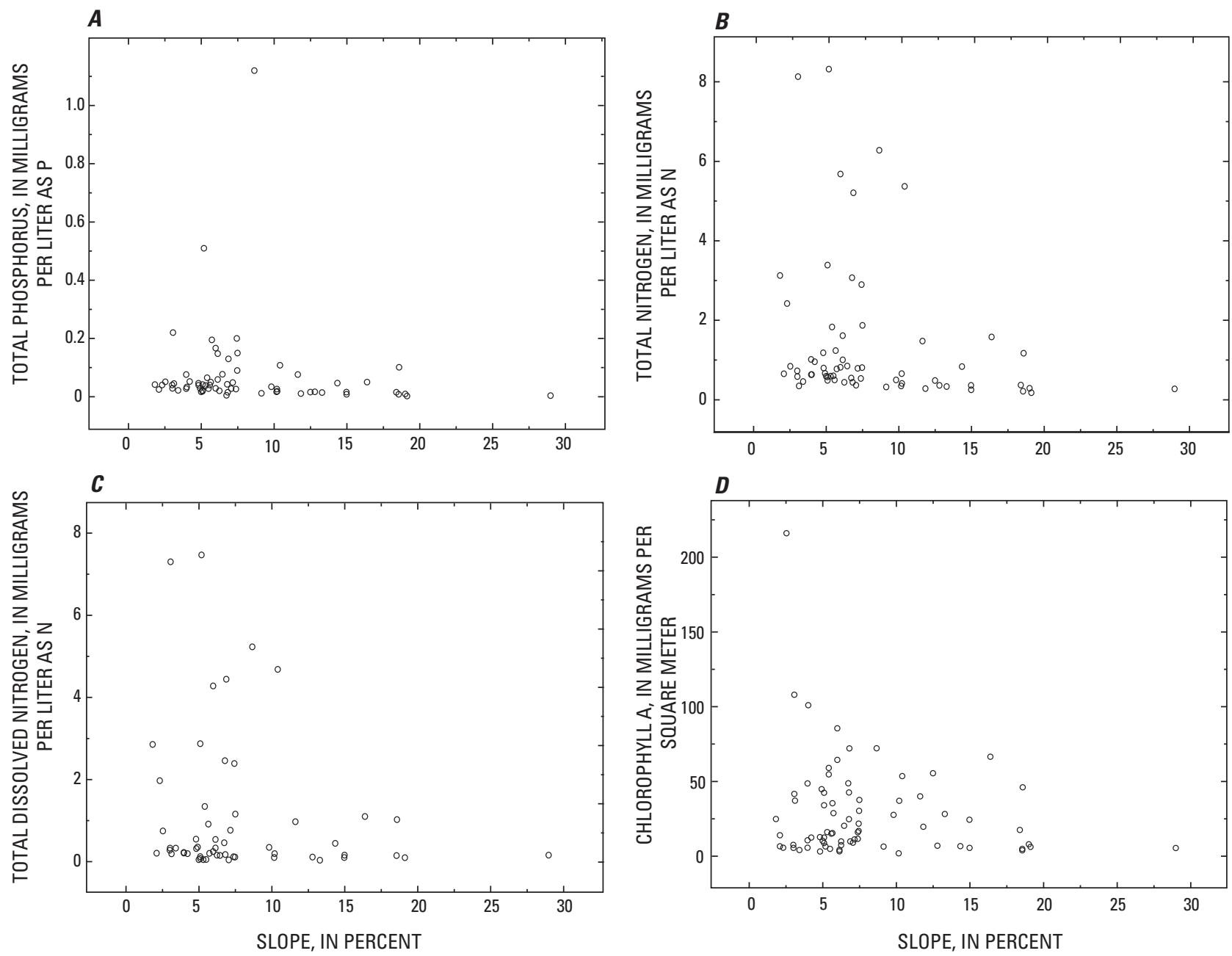

Figure 17. Median $(A)$ total phosphorus, $(B)$ total nitrogen, $(C)$ total dissolved nitrogen, and $(D)$ chlorophyll $a$ concentrations at all sampling sites as a function of slope in Massachusetts. 
For additional information write to:

Director

USGS Massachusetts-Rhode Island Water Science Center

10 Bearfoot Road

Northborough, MA 01532

or visit our Web site at

http://ma.water.usgs.gov 
